\title{
Can a Pregnant Woman Morally Refuse Fetal Surgery?
}

\author{
Katherine A. Knopoff $\dagger$
}

Fetal surgery techniques may soon improve so that the benefits to the fetus will outweigh the risks to the pregnant woman. Under such a scenario, utilitarianism-which seeks the greatest overall societal benefitwould require surgical intervention to treat the fetus, even if the woman refused the surgery. This Comment argues, however, that deontology provides the better decisionmaking framework for the fetal surgery context. Since deontology, as embodied in the informed consent doctrine, applies in all other medical decisionmaking contexts, there must be a compelling reason to change the framework for fetal surgery. One reason that might be offered is the apparent conflict between the woman's right to refuse surgery for herself and her duty to permit the fetus to be treated. The author proceeds to resolve that conflict in favor of the pregnant woman's right to refuse the fetal surgery, and accordingly she concludes that no justification remains for abandoning deontology in the fetal surgery context.

\section{INTRODUCTION}

When the law fails to keep pace with medical technology, decisions about the proper course of action are often haphazard and superficial. Rights can get trampled before lawmakers consider the new area and determine how to address it. At times, existing law may not cover the kinds of problems accompanying advances im medical procedures, or people, unaware of any existimg law, apply their own notions of the proper course of action.

Therapeutic fetal surgery is an example of the clash between new medical technology and a legal system that is out of step. ${ }^{1}$ Such surgery has in recent years saved the hives of many babies for whom there once

$\dagger$ B.A. 1985, Stanford University; M.A. 1986, Stanford University; J.D. candidate 1991, Boalt Hall School of Law, University of California, Berkeley.

1. Other recent problents that have occurred because the law failed to keep up with technology have led to cases such as Moore v. Regents of the University of California, $51 \mathrm{Cal}$. 3d 120, 793 P.2d 479, 271 Cal. Rptr. 146 (1990) (concerning the ownership of a patient's cells) and Davis v. Davis, No. E-14496 (Teun. Ct. App. 1989) (LEXIS, States library, Tenn file) (determining the disposition of frozen embryos upon their parents' divorce). Before developments in technology permitted cell cloning, geue splicing, and ni vitro fertilization, couficts like these siniply did not exist. 
was no hope. ${ }^{2}$ But while many people are enthusiastic about the possibility of early treatment for their future children, what about those parents who are not? Fetal surgery requires surgery on the pregnant woman. Yet by refusing surgery for herself she refuses treatment for her fetus. Her interest in not being subjected to unwanted bodily intrusions is in conflict with the state's imterest in the life and well-being of the fetus. ${ }^{3}$

Forcing a woinan to undergo fetal surgery against her will seems inconceivable today, although not long ago one might have said the sane about forcing a woinan to undergo a cesarean section. Yet the latter is already a reality. Much has been written recently about cesarean sections performed against the express wishes of pregnant woinen. ${ }^{4}$ The hiterature primarily addresses several cases in which courts ordered or were asked to order cesarean sections after competent pregnant woinen refused to give consent. ${ }^{5}$ State-compelled cesarean section is similar to state-compelled fetal surgery in that the pregnant woman is forced to undergo serious bodily intrusion for the sake of a fetus whose unhealthy condition she has not caused. ${ }^{6}$ Although no case has yet arisen where a court has been asked to order therapeutic fetal surgery against a pregnant woman's wishes, there is no reason to think such a case is far off.

2. See Successful Heart Surgery on a Fetus Inside Womb, San Francisco Chron., Feb. 1, 1990, at A3, col. 5.

3. See infra text accompanying note 64 .

4. See, e.g., G. ANNAS, JUDGing MEdicine 119-25 (1988); Bowes \& Selgestad, Fetal Versus Maternal Rights: Medical and Legal Perspectives, 58 OBstetrics \& GYNECOLOGY 209 (1981); Chervenak \& McCullough, Perinatal Ethics: A Practical Method of Analysis of Obligations to Mother and Fetus, 66 Obstetrics \& GYNeCOlogy 442 (1985); Dal Pozzo \& Marsh, Psychosis and Pregnancy: Some New Ethical and Legal Dilemmas for the Physician, 156 AM. J. OBSTETRICs \& GYNECOLOGY 425 (1987); Engelhardt, Current Controversies in Obstetrics: Wrongful Life and Forced Fetal Surgical Procedures, 151 AM. J. OBSTETRICs \& GYNECOLOGY 313 (1985); Fletcher, Drawing Moral Lines in Fetal Therapy, 29 CliniCAl OBsTETRICs \& GyNecology 595 (1986); Gallagher, Prenatal Invasions \& Interventions: What's Wrong With Fetal Rights, 10 HARv. Women's L.J. 9 (1987); Jurow \& Paul, Cesarean Delivery for Fetal Distress Without Maternal Consent, 63 ObsteTrics \& GyNeCOLOGY 596 (1984); Myers, Abuse and Neglect of the Unborn: Can the State Intervene?, 23 DuQ. L. REv. 1 (1984); Nelson, Buggy \& Weil, Forced Medical Treatment of Pregnant Women: "Compelling Each to Live as Seems Good to the Rest," 37 Hastings L.J. 703 (1986); Rhoden, The Judge in the Delivery Room: The Emergence of Court-Ordered Cesareans, 74 Calif. L. REv. 1951 (1986); Robertson, Legal Issues in Fetal Therapy, 9 Seminars IN Perinatology 136 (1985) [hereinafter Robertson, Fetal Therapy]; Robertson, The Right to Procreate and In Utero Fetal Therapy, 3 J. LeGAl MED. 333 (1982) [hereinafter Robertson, The Right to Procreate]; Rosner, Bennett, Cassell, Farnsworth, Landolt, Loeb, Numann, Ona, Risemberg, Sechzer \& Sordillo, Fetal Therapy and Surgery: Fetal Rights Versus Maternal Obligations, 89 N.Y. ST. J. MED. 80 (1989).

5. See Gallagher, supra note 4, at 11 n.16 (listing ten reports of forced cesareans). For a representative case, see Jefferson v. Griffin Spalding County Hospital Authority, 247 Ga. 86, 274 S.E.2d 457 (1981) (woman with placenta previa ordered to undergo cesarean). See infra note 63 (summarizing Jefferson).

6. This is unlike the pregnant drug abuser, for example, who is indeed the cause of her fetus' harm and who therefore seems more deserving of imposed reparations. See infra notes 103.09 and accompanying text. 
Decisions about how to treat legal problems arising from the use of new technology ought to be made before the implementation of that technology. Although doctors have already begun surgically treating fetuses during pregnancy, they are doing so in the absence of any clear statement of applicable law. We must define the law immediately, to avoid ad hoc and inconsistent decisionmaking that may trample on individual rights and choices.

With time, the techniques imvolved in fetal surgery will improve, providing greater benefit to the fetus than risk to the health of the pregnant woinan. A utilitarian approach would balance the risks and benefits and would require intervention in such a situation. ${ }^{7}$ By contrast, deontological theory would require respecting the rights of those mvolved, regardless of the result. We must decide which theory is proper in order to determine what the law should be.

This Comment argues that utilitarianism is an mappropriate framework for choosing a course of action in the fetal surgery context and explains why deontological theory, as it underlies the doctrine of inforined consent, provides the proper franiework for forınulating a fetal surgery law. After resolving the apparent conflict of rights raised by the apphication of deontological theory in this context, the Comment proposes a deontological fetal surgery law based on ordinary inforined consent principles.

I

Fetal SURGERY

\section{A. The Conflict}

Historically, the fetus had hittle recognized existence before birth since no one could see it. Instead, it was perceived-actually and legally-as part of the woinan. ${ }^{8}$ Until recently, tort, criminal, and property laws required that a fetus be born alive before daniages,

7. John Robertson argues that although parents and doctors can choose whether to try fetal surgical therapy while the procedures are experimental, parents and doctors have a duty to treat the fetus with these procedures once they are considered safe and effective-if the woman has shown her intent to carry the fetus to term by not aborting. Robertson, The Right to Procreate, supra note 4, at 352.

8. Lenow, The Fetus as a Patient: Emerging Rights as a Person?, 9 AM. J. Legal Med. 1, 6 (1983).

9. Id. at 5-6. Tort statutes required live birth in order for the parents to recover damages for the wrongful death or injury of their fetus in utero. See Dietrich v. Inhabitants of Northampton, 138 Mass. 14, 16 (1884) (Hohnes, J.) (premature child who survives only "a few minutes" following delivery is not a person for purposes of civil hability). But cf. Presley v. Newport Hosp., 117 R.I. $177,187,365$ A.2d 748, 753 (1976) (stillborn infant, whether viable or not, is a person within the meaning of the Wrongful Death Act). Live birth is still required in some states. Lenow, supra note 8 , at 5 n.36. 
punishment, ${ }^{10}$ or inheritance ${ }^{11}$ could be obtained on its behalf. Developments in medical technology, especially the advent of ultrasound, have given the fetus a presence before birth: doctors can now see the fetus' form, discover its sex, monitor its heart rate, and check it for genetic defects and chemical imbalances.

While most women would want doctors to do everything to ensure dehivery of a healthy baby, some women niay have preferences that are at odds with and that are, to them, niore important than the doctors' perception of the fetus' needs. In the past, treatment of the fetus meant maintaining the pregnant wonian's health; treatment was often no inore physically burdensome than taking vitainins. Today, treating the fetus may involve ultrasound examination, amınocentesis, medication, transfusion, anesthesia, and surgery. Although a pregnant wontan may have few qualms about accepting relatively minor fetal treatnient, new types of fetal treatinent niay be daunting, especially if the procedure conflicts with her rehigious behefs, her fear of surgery, her desire to avoid risks, her uncertainty about the results, or her wish not to be burdened with raising a severely handicapped child who is saved by the treatment but not cured.

The ability to see the fetus as a distinct entity and the recognition that the pregnant womran's and fetus' needs are not always synonynious have led doctors to consider that not one but two patients present theinselves when a pregnant woman seeks prenatal care. ${ }^{12}$ A wonian's refusal to allow fetal treatment creates a dilemina, because the doctor perceives both woman and fetus as patients and perceives that a duty of professional medical care is owed to both. To which patient does the doctor owe the superior duty? Which patient's interests should prevail? New inedical technology forces us to determine how to resolve the conflicts that have arisen and that will continue to appear. The next Section examines the new technology and procedures that have led to the fetal surgery conflict.

10. Lenow, supra note 8, at 4-5. As with tort law, the criminal law imposed no penalty for feticide unless the fetus was born alive before dying. Thus, abortion was not homicide unless the fetus was born alive but subsequently died. Homicide statutes were later amended to include killing a fetus, thus paving the way for a widespread ban on abortion.

11. Id. at 3. Although a fetus had property rights, they were contingent on its live birth, at which point those rights would vest. See In re Peabody, 5 N.Y.2d 541, 547, 158 N.E.2d 841, 845, 186 N.Y.S.2d 265,270 (1959) (fetus "not regarded as a person until it sees the light of day"). This position still holds in state property statutes today.

12. Lenow, supra note 8, at 2 ("Happily, we have entered an era in which the fetus is established as our second patient.") (quoting J. Pritchard \& P. MacDonald, Williams OBSTETRICS VII (16th ed. 1980)). 


\section{B. Technological Advances That Have Led to the Conflict}

Recent advances in prenatal diagnosis, which allow detection of many fetal defects and conditions, have made fetal surgery possible. Amniocentesis, the withdrawal by needle of a small amount of the amniotic fluid surrounding the fetus, was first used in 1967 and today can be used to detect about 100 fetal genetic abnormalities. ${ }^{13}$ Ultrasound, which uses sound waves to create a visible image of the fetus on a television screen, allows doctors to see the size and shape of the fetus' organs and limbs, even parts as sinall as external genitals or an upper hp. ${ }^{14}$

New technology not only helps doctors detect abnormalities imtially, but also permits doctors to operate on fetuses while the fetuses are still developing. ${ }^{15}$ Ultrasound shows the otherwise "blind" surgeons the fetus' position and movements in the uterus during fetal surgery. ${ }^{16}$ Additionally, labor-inhibiting drugs, ordinarily used to prevent premature dehivery, can be administered to ward off labor that fetal surgery might otherwise trigger. ${ }^{17}$ Fetuses with defects that can wait for treatınent until after birth are not candidates for surgery during pregnancy. Rather, fetal surgery is used to correct only those defects that will either kill the fetus before birth or cause the fetus progressive and irreversible damage if left untreated until after birth.

Although doctors anticipate the development of many innovative types of fetal surgery, ${ }^{18}$ at present only two surgical procedures ${ }^{19}$ have been performed in any significant number. ${ }^{20}$ The first procedure is for the treatment of hydrocephalus, a condition that causes fluid to accumulate in the bram, increasing pressure inside the skull, thereby preventing

13. Henig, Saving Babies Before Birth. N.Y. Times, Feb. 28, 1982, §6, at 22, col. 3.

14. Id.; see also Chervenak, Isaacson \& Mahoney, Current Concepts: Advances in the Diagnosis of Fetal Defects, 315 NEW ENG. J. MED. 305, 305 (1986) (discussing the routine study of sinall fetal structures).

15. Although most fetal surgery occurs while the fetus is still inside the uterus, in the case of Baby Mitchell, doctors at U.C.-San Francisco removed a fetus from the mother's uterus through a cesarean section, successfully imblocked the fetus' urinary tract, and returned the fetus to the uterus for continued development until its birth nine weeks later. Blakeslee, Fetus Returned to Womb Following Surgery, N.Y. Times, Oct. 7, 1986, at C1, col. 6.

16. Henig, supra note 13 , at 22 , col. 4 .

17. Id. at 26 , col. 3 .

18. Id. at 22, cols. 1-2.

19. Actually, a third is reported by Jonsen, The Ethies of Fetal Surgery, in GENETICS AND THE LAw III 365, 365 (A. Milunsky \& G. Annas eds. 1985) ("The third surgical treatinent considered fcasible is correction of congemital diaphragmatic hernia [which pushes the liver up into the chest]. This procedure has not yet been done [on human fetuses]."). A fourth is heart surgery. See Successful Heart Surgery on a Fetus Inside Womb, supra note 2, at A3, col 5.

20. Manning, International Fetal Surgery Registry: 1985 Update, 29 ClINICAL OBSTETRICS \& GYNECOLOGY 551 (1986). This registry, whose statistical studies are based on data drawn from voluntary submissions, medical literature, and inquiry at the major fetal surgery centers, reported surgical fetal therapy for 72 cases of hydronephrosis, 39 cases of hydrocephalus, and 1 case of diaphragmatic hernia. 
the development of brain cells and causing the head to swell. ${ }^{21}$ Although rarely fatal, untreated hydrocephalus causes severe mental and physical handicaps due to brain dainage. ${ }^{22}$ Treatınent for hydrocephalic fetuses involves insertimg a shunt, a thin tube that acts as a one-way valve, through the abdomen and uterus of the pregnant woinan and, gnided by ultrasound, into the lateral ventricle of the fetus' brain. ${ }^{23}$ The shunt allows excess brain fluid to drain into the amniotic space around the fetus, which greatly reduces the pressure on its brain, allowing brain development to contimue unimpeded. ${ }^{24}$

Unfortunately, although about $85 \%$ of treated fetuses survive, about half of them are born mildly or severely handicapped. ${ }^{25}$ Since it is still too soon for long-term follow-up studies, even those babies who now appear normal may yet show signs of handicap as they grow up. ${ }^{26}$ These disappoimting results stem from the fact that fetal hydrocephalus is only detectable late in the pregnancy, after irreversible brain damage has already occurred. ${ }^{27}$ For the present, doctors have stopped performing fetal hydrocephalus surgery. ${ }^{28}$

The second surgical procedure is for the treatment of fetal hydronephrosis, a condition in which an obstrncted urinary tract causes the urine in the fetus' bladder to back up and accumulate in the abdoinen. The resulting pressure causes permanent damage to the kidneys. ${ }^{29}$ Since the fetus is unable to urimate, it produces no amniotic fluid, ${ }^{30}$ which is necessary for lung development. ${ }^{31}$ Although fetuses with partially obstructed urinary tracts can wait for treatment until birth, those fetuses with complete blockages, if not treated in the uterus, will likely die at or soon after birth. ${ }^{32}$

Complete urinary tract blockage can be detected by ultrasound early in pregnancy because the fetus' bladder and abdomen are inuch larger

21. Henig, supra note 13 , at 18 , col. 1 .

22. Clewell, Congenital Hydrocephalus: Treatment In Utero, 3 FETAL THERAPY 89, 90-93 (1988).

23. Id. at 95 .

24. Id. at $95-96$.

25. Id. at 96.

26. Id.

27. Annas \& Elias, Perspectives on Fetal Surgery: On the Road From Experimentation to Therapy (and What to Do When We Arrive), in GeNETICS AND tHE LAW III, supra note 19, at 349; Clewell, supra note 22, at 96.

28. Clewell, supra note 22, at 96.

29. E. Volpe, PAtient in THE Womb 132 (1984); Annas \& Elias, supra note 27, at 350; Henig, supra note 13 , at 28 , col. 4 .

30. Amniotic fluid consists primarily of fetal urine. Blakeslee, supra note 15, at C3, col. 3 .

31. Id.

32. See Annas \& Elias, supra note 27 , at 350 . By the time of birth, the lungs and kidneys arc too underdeveloped or badly damaged to improve. E. VOLPE, supra note 29, at 132. 
than normal and because amniotic fluid is absent. ${ }^{33}$ Like the operation for hydrocephalus, treatment for fetal hydronephrosis usually involves inserting a shunt into the fetus' bladder to drain the urine into the amniotic space. ${ }^{34}$ Because the condition is detectable so early in the pregnancy, most babies born after treatment for hydronephrosis appear to be doing well. ${ }^{35}$

The ever-advancing state of the art in therapeutic fetal surgery will improve the outlook for more and more affected fetuses. Nevertheless, substantial risks from anesthesia and surgery remain for the pregnant woman, ${ }^{36}$ who may therefore wish to refuse the surgery. Should she be permitted to refuse? The next Section examines theories for analyzing and ultimately resolving this apparent conflict involved in fetal surgery.

\section{II}

\section{Finding A Theory: UtilitarianisM OR DeONTOLOGY}

Two theories, utilitarianism and deontology, provide possible bases for consideration of the morality of forced fetal surgery. Utilitarian theory recommends choosing the course of action that best promotes the general welfare, or that procures "the greatest happiness of the greatest number." 37 In a utilitarian analysis, the appropriate method of determining the best outcome involves the balancing of risks against benefits, disadvantages against advantages, pain against pleasure. Utilitariainism requires following the course of action that leads to the best possible outcome, and the ends are permitted to justify the means.

Deontological or rights-based theory, in contrast, demands that the means justify the ends. ${ }^{38}$ Deontology maintains that every action is inherently right or wrong. Right actions usually involve fulfilling one's existing duty to others and respecting their rights. Wrong actions involve ignoring existing duties and rights. How one's acts affect the outcome, however, is irrelevant to the deontological calculation. Deontology requires following the course of action that imvolves ouly right acts,

33. E. VOLPE, supra note 29 , at 132 \& n.2.

34. Annas \& Ehias, supra note 27 , at 350 . In some cases, the urine build-up can also be treated by partially removing the fetus from the uterus: then the surgeon either cuts a hole in the fetus' abdomen and bladder and sews the bladder to the skin around the hole in the abdomen; or the surgeon cuts two holes in the fetus' back and sews the ureters (which carry urine from the kidneys to the bladder) to the skin around the holes iu the back. More surgery is necessary after birth to allow normal urination. Blakeslee, supra note 15, at C3, col. 5.

35. Blakeslee, supra note 15, at C3, col. 6. As of 1986, of the 79 fetuses who received bladder shunts, 45 died or were aborted before birth. Of the 34 surviving babies, all but one are doing well. Id.

36. See infra notes $142-50$ and accompanying text.

37. 10 THE WORKS OF JEREMY BeNTHAM 142 (J. Bowring ed. 1843).

38. See S. SChEFFler, THE REJECTION OF CONSEQUENTIALISM 2-3 (1982). 
never compromising rights or duties for the sake of the outcoine. ${ }^{39}$

In the world of doctor and patient, a utilitarian framework for health care decisionmaking requires increasing the general welfare by maximizing the overall level of human health. The means are irrelevant, as long as society reaches the goal of maximum possible health. For example, the state in its health-maximizing agenda might require doctors to treat people, ${ }^{40}$ regardless of the their willingness to undergo the procedures or their desire to visit doctors at all. ${ }^{41}$

Similarly, a patient who requires expensive health treatment, such as hospital care for preınature or drug-addicted newborns or major surgery, may be denied treatment because it siphons funds beyond the patient's share. Common life-extending procedures, such as heart bypass surgery, will thus be unjustified as too expensive. Under the utilitarian view, where the goal is maximizing overall human health, funds are better spent making several people healthy than making just one person healthy.

Finally, since means are irrelevant to achieving desired ends in a utilitarian world, a healthy person's organs could be used to save two or more people's lives since the net saving of lives would nicrease overall human liealth. This extreme but logical result of a utilitarian lealth care systein evokes the nightmarisli visions of John Harris' perfectly utilitarian organ lottery, which proposed random selection of a citizen by lottery as a fair way of choosing the sacrificial societal organ donor. ${ }^{42}$ Under this scheine, life and health are very good for most people, the nondonors, who are assured of replacements for their unhealthy organs. On the other hand, life is bad for only a few people, who must die to make their organs available. Yet these few are only unhappy for the short time between learning of their selection and their deaths, and they die secure in the knowledge that they are helping to maximize overall health and tlius are model utilitarian citizens. ${ }^{43}$

39. For example, utilitarianism would find that if killing one person for his organs could save five dying people's lives, killing him would be required because, in the final count, fewer people die. Deontology would find that because it is wrong to kill a person for his organs, the person could not be killed, no matter low many others may die as a result.

40. It is clear that treating one person can affect the lealth of others, as with the treatment of infectious diseases. It is also true that the person treated may not need the treatment for her own liealth, as with the control of infectious disease by vaccination, bone marrow donation, and fetal surgery. To mcrease the overall level of health, a liealthy person would have to undergo treatment if it improved the collective health of others more than it harmed her own.

41. Presumably the state would set up some scheme whereby people would have regular, required checkups for lealth improvement, and it would also require them to seek treatment when ill. People would have to submit to whatever treatment the doctor prescribed, with penalties for trying to escape any part of the scheme.

42. See Harris, The Survival Lottery, 50 PhILOSOPHY 81 (1975).

43. See id. 
In contrast, a deontological model for decisionmaking bases the proper course of action on the rights and duties of those involved. In the world of doctor and patient, if the doctor suggests a course of treatment, the patient has a right to refuse the treatment and the doctor has a duty to respect her refusal. This familiar deontological model currently guides decisionmaking im the doctor-patient relationship, in the form of the doctrine of inforined consent. ${ }^{44}$

Thankfully, our health care system generally does not operate in a utilitarian manner. ${ }^{45}$ Nevertheless, some commentators beheve that the utilitarian approach achieves the proper balance in the fetal surgery context. ${ }^{46}$ But if informed consent is the deontological model we use for all other situations involving doctor-patient decisionmaking, what justifies switching to a utilitarian model just for pregnant women?

The attraction of utilitarianism in this context may well result from confusion as to the proper deontological course of action. Although the pregnant woman has a right under the inforined consent doctrine to refuse fetal surgery and the doctor has the duty to respect her refusal, the woman may also have the conflicting duty to allow fetal treatment. ${ }^{47}$ Since it would be wrong to impose treatment on a patient aganist her will, and since it would also be wrong to deny the fetus treatment if the woinan has a duty to allow it, the proper deontological course of action is unclear.

If we can resolve the apparent conflict of rights and duties so that the proper deontological course of action becomes clear, then there is no longer any need to abandon the deontological model, which otherwise applies to doctor-patient decisionmaking. This Comment resolves this apparent conflict between the pregnant woman's right to act

44. For a discussion of this doctrine, see infra notes $78-90$ and accompanying text.

45. At times the state does require people to undergo health treatment for their own sake, but almost never when the patients are competent. See infra notes $84-85$ and accompanying text. The state also, at times, requires people to undergo health treatment for the sake of others. See Jacobson v. Massachusetts, 197 U.S. 11, 28 (1905) (upholding state law unposing fine on mdividuals who did not get vaccinated). But see, e.g., McFall v. Shimp, 10 Pa. D. \& C.3d 90 (Allegheny County Ct. 1978) (bone marrow donation held not compulsory, even if it could save soineone else's life).

Compulsory vaccimation can be distimguished from coinpulsory bone inarrow donation in that the benefit in the former is widespread and generalized; requiring someone to submit under those circumstances seems more acceptable than when the benefit is particularized to an identifiable individual. See McFall, $10 \mathrm{~Pa}$. D. \& C.3d at 92 . In addition, the state has an interest in protecting its population at large, but not one person's health in particular. The same primciple justifies sending someone to war to risk his life for the benefit of the country as a whole, but would not justify asking someone to risk his life for the benefit of another. On this same principle, then, coinpulsory fetal surgery can also be distimguished in that it does not render a generalized public benefit.

46. See infra notes 48-51 and accompanying text; see also Robertson, The Right to Procreate, supra note 4, at 351-52 (arguing from a utilitarian standpoint that doctors must try fetal surgery once it is considered safe and effective).

47. See infra notes 97-109 and accompanying text. 
autonomously by refusing surgery and her duty to permit the fetus to be treated. The existence of this duty would curtail the woman's autonomy, would eliminate her right to refuse, and would thus require an exception to the informed consent doctrime im cases of recommended fetal surgery. In the next Sections, we will examine the competimg rights and duties mvolved to determine whether any reason exists for deviating from the informed consent doctrime.

\section{III}

\section{FETAL RIGHTS AND INTERESTS}

\section{A. Proposed Theories of Fetal Rights}

Fetal rights supporters propose that the fetus has the right to be born healthy, if at all. ${ }^{48}$ Those who support fetal rights in situations where maternal and fetal interests clash rarely insist that fetal rights are simply superior to the woman's rights. Instead, most adopt a utilitarian approach and employ some form of balancing test, weighing the fetus' right to be born healthy against the pregnant woman's right to act as she pleases.

To that end, John Robertson proposes that a pregnant woman, while under no duty to use experimental surgical procedures to treat her fetus, does have a duty to use medically established procedures to treat it if she imtends to bring the fetus to term. ${ }^{49}$ To Robertson, the woman signals that intent by forgoing her right to abort the fetus. ${ }^{50}$ Under Roe v. Wade, the pregnant woman forgoes her right to abortion at the end of the second trimester, at the representative point of fetal viability, but only if the state has chosen to restrict the right and if her life and health

48. Note that current law does not give the fetus the right to be born until it reaches viability, and only then if the birth poses no risk to the pregnant woman's health or life. See Roe v. Wade, 410 U.S. 113, 164-65 (1973). Under Roe, the state may proscribe abortion during the third trimester of pregnancy but is not required to do so. During the first two trimesters, and during the third if pregnancy puts the woman's health at risk, the statc cannot limit a woman's right to abort the fetus and may not consider the fetus' rights.

49. Robertson, The Right to Procreate, supra note 4. I disagree with Robertson's intent-based model because the simple fact of uot aborting indicates very little about a woman's intent to bring her fetus to term. Many pregnant women refuse to abort because of religious beliefs or fear of invasive medical procedures. Others fail to abort because of madequate knowledge of their options and legal rights, or because of shame, familial or societal pressure, poverty, or lack of access to abortion clinics.

50. Id. at 352. As long as Roe is the law, the pregnant woman would always have the option of aborting during the first two trimesters rather than undergoing surgery for the sakc of her fetus. If an abortion werc necessary for her life or health at any time during the pregnancy, Roe would allow her to abort rather than submit to fetal surgery. In virtually all fetal surgery situations, however, the condition for which the fetus needs treatment poses no risk to the woman's health; treatment is solely for the fetus' sake. This is different from many of the forced cesarean cases, where the cesarean is necessary for the health of both the woman and the fetus. 
are not endangered by such restriction..$^{51}$

Robertson does not recognize that a fetus can suffer a great deal of damage before the point where, according to his theory, a woman has a duty to take "all reasonable measures, including einploying establislied, in utero therapies, to minimize damage to the child."52 Has a pregnant woman no duty until the third trimester to refram froin harming ler fetus by, for example, sinoking crack cocame? Has she no duty until the third trimester to have her fetus treated for hydronephrosis, if the surgery is no longer experimental, if the condition is detected early enough to cure the defect, and if waiting until the third trimester damages the fetus' kidneys and lungs beyond repair?

If Robertson wants to use this model to protect the rights of the fetus, he cannot draw the line at the point where the pregnant woman can no longer abort and still expect to help many fetuses. He could push the line back to the point where the woinan intends to bring the fetus to term, which could be inuch earlier than viability. Yet assessing that intent would be all but impossible, and nothing would prevent a woman who intends to bring her fetus to term from later clianging her mind and aborting. 53

Margery Shaw goes a bit further than Robertson does to protect fetal rights. ${ }^{54}$ She proposes an additional, limited maternal duty during the period when the woman can still legally abort. The woman must refram from liarming the fetus by abusing drugs or alcohol and must offer the fetus all aid that is minimally burdensome, such as having regular prenatal checkups and taking vitamin suppleinents. ${ }^{55}$ Only after the pregnant woman has forgone her right to abortion does the burden of the maternal duty increase. Then she must aid the fetus by undergoing more invasive procedures, such as fetal surgery, if necessary for the fetus and not too harmful for the wolnan. ${ }^{56}$ Like Robertson, Shaw does not require the woman to undergo invasive procedures to aid her fetus until the third trimester, even though the damage to the fetus unay at that poimt be irreversible. Like Robertson, Sliaw does not require the woman to undergo surgery that would be dangerous to her health.

In an analysis that leads to the same conclusion, Deborah Mathieu posits that a woman, upon becoming pregnant, assumes the saine duty of care toward the fetus as she would toward any stranger: a duty to simply

51. Roe, 410 U.S. at $164-65$.

52. Robertson, Fetal Therapy, supra note 4, at 139.

53. See infra note 62.

54. See Shaw, Conditional Prospective Rights of the Fetus, 5 J. Legal MED. 63 (1984).

55. Id. at 83 .

56. Id. at 88. Were the state to choose not to proscribe abortion after fetal viability, as is possible under Roe, the woman would never forgo her right to abortion and thus would not be subject to this more burdensome duty. 
refrain from causing harm. ${ }^{57}$ Her duty terminates should she decide to terminate the pregnancy. ${ }^{58}$ If, however, she forgoes her right to abort, she shows her willingness to enter a special relationship with the fetus, with the accompanying stricter duty of care. ${ }^{59}$ This stricter duty requires her to aid the fetus by agreeing to fetal surgery if necessary, as long as the procedure is significantly likely to help or cure the condition, ${ }^{60}$ and as long as the untreated fetal condition would cause more harm to the fetus than the woman would suffer by undergoing the surgery. ${ }^{61}$

These three fairly similar proposals typify a balancing-of-interests approach to fetal surgery decisionmaking. Although invoking duties not to harm, duties to treat, and special relationships sounds deontological, selecting the point of fetal viability merely provides a more palatable cutoff point for imposing what is in fact utilitarian balancing. ${ }^{62}$ The saine sort of utilitarian balancing has characterized the few court decisions ordering invasive medical procedures (cesarean section and intrauterine blood transfusions) for the sake of the fetus against the pregnant woman's wishes. ${ }^{63}$

The justification for this utilitarian balancing is apparently based on

57. Mathieu, Respecting Liberty and Preventing Harm: Limits of State Intervention in Prenatal Choice, 8 Harv. J.L. \& PuB. Pol'y 19, 36-37 (1985).

58. Id. at 37.

59. Id.

60. Id. at 52 .

61. Id. at 54. This formula would almost always indicate surgery, simce the certain harms of severe brain damage from untreated hydrocephalus or death from untreated hydronephrosis would almost always outweigh potential harms to the woman from anesthesia and surgery.

62. Any woman adamantly opposed to fetal surgery presumably would choose to abort the unhealthy fetus instead. See Rhoden, supra note 4, at 2008 (citing Kerenyi \& Chitkara, Correspondence to the Editor, 305 NEw ENG. J. MED. 1219 (1981)). Therefore, the utilitarians must coudition the woman's duty to undergo fetal surgery on the unavailability of abortion.

Although viability is the obvious point after which abortion may no longer be legally available (if the state has chosen to bar post-viability abortions, as Roe permits them to do), this is a practical and not a moral constraint on the availability of abortion. The moral unavailability of abortion arises once the woman decides not to abort. Once she decides to carry the fetus to term, the resulting moral unavailability of abortion would presumably require her to undergo fetal surgery if uecessary. But what prevents the woman from changing her intention not to abort once she learns that the alternative might require her to undergo fetal surgery? Changing her intention makes abortion morally available and fetal surgery not required. For this reason, it is much easier to apply the utilitarian approach within the existing legal constraints than within the underlying moral frainework.

63. See, e.g., Jefferson v. Griffin Spalding County Hosp. Auth., 247 Ga. 86, 274 S.E.2d 457 (1981). In Jefferson, the Georgia Supreme Court upheld a lower court order requiring a woinan who had refused a cesarean section to submit to the surgery. The woman, who lad refused the surgery on religious grounds, had placeuta previa, a condition in which the placenta blocks the baby's exit from the uterus. Vaginal delivery with placenta previa would have led to the almost certain death of the fetus and a $50 \%$ cliance that the woinan would die by hemorrhage. The court found that "the intrusion involved into the bfe of [the woman] and ler husband ... is outweighed by the duty of the State to protect a living, unborn human being from meeting his or her death before being given the opportunity to live." Id. at 89,274 S.E.2d at 460 . The order was rendered moot when the placenta slifted position, making vaginal delivery unproblematic. 
the state's compelling interest in the fetus, as announced in Roe v. Wade. ${ }^{64}$ By invoking the viability standard, these authors make new moral determinations based on the legal framework set out by Roe. But what happens when the law changes? ${ }^{65}$ Unless these writers believe that viability has moral significance, they are using the legal construct without questioning its appropriateness. ${ }^{66}$ This seems an odd practice for moral theorists. I find fault with their failure to justify or even to examine their abandonment, in this one context, of the usual deontological model of doctor-patient decisionmaking as embodied in the informed consent doctrime.

I do not argue that legal frameworks are irrelevant, but ratlier that they should be morally justifiable. In fact, laws can often provide imsight into societal conceptions of morality. The next Section explores legal and moral concepts of the fetus in an attempt to determine whether the fetus has rights that would require an exception to the informed consent doctrine in the fetal surgery context.

\section{B. The Personhood Rights of a Fetus}

The legal debate over whether a fetus is a person is not, in reality, a debate over scientific facts. It is a debate over the moral status of the fetus, that is, low the fetus ought to be treated. Legal personhood is no more than a construct describing the common characteristic of a group of entities to whicl we ascribe certain rights. ${ }^{67}$ Furthermore, trymg to determine by comparison with other members of the group whether or

64. 410 U.S. 113,159 (1973).

65. In fact, the current Supreme Court would probably reject Roe $v$. Wade's viability standard. The recent Supreme Court decision of Webster v. Reproductive Health Services, 109 S. Ct. 3040 (1989), shows the desire of a majority of the Justices to overrule the viability and trimester framework of Roe. Webster, 109 S. Ct. at 3067 (Blackmun, J., dissenting). The majority has probably been strengthened by the retirement of Justice Brennan, a Roe supporter. The current, predominantly conservative Court may decide, should the proper abortion case come before it, that the state's interest in fetal health outweighs the woman's right to abort at all times during pregnancy, unless the woman's health is at risk.

This does not imply that where fetal health and maternal health confict, as in the fetal surgery context, the state's interest in fetal health would necessarily be superior to its interest in maternal health. In deciding a fetal surgery case, the Court would probably perform a utilitarian balancing of the projected benefit to the fetus against the likely risk to the woinan from undergoing the surgery, and would presumably find in favor of the fetus. Although this is the likely analysis, it is not, in uny view, the proper one.

66. Roe arrived at the viability and trimester framework after applying a utilitarian analysis to balance interests in the abortion context, an analysis unjustified in doctor-patient decisioninaking but understandable as a politically expedient compromise in the Supreme Court case. Resort in the abortion case to utilitarian analysis can also be explained by the fact that the informed consent doctrine is not as relevant to abortion decisions, because the doctrine gives a person the right to refuse recommended treatment, not the right to compel treatment. See infra note 83 .

67. This definition of personhood is reflected in Roe v. Wade, 410 U.S. 113, 158 (1973), which holds that the fetus is not a person for purposes of the fourtecnth amendinent. 
not a fetus has membership may be impossible. ${ }^{68}$ In any case, that inquiry does not address directly the real issue of how the fetus ought to be considered. A great deal has been written about the moral and legal status of the fetus. ${ }^{69}$ Many writers have tried to isolate the essential criterion of personhood in the moral sense to determine whether the fetus possesses this quality. Some scholars beheve the essential trait of inoral personhood is consisting of umiqu, he, human genetic inaterial. ${ }^{70}$ Fetuses are included in this definition because of their composition and their potential for becoming what we all think of as persons. Others have isolated the essential quality of moral personhood as the possession of a collection of traits, primarily consciousness, rationality, self-awareness, emotional capability, and the ability to plan aliead. ${ }^{71}$ Fetuses are excluded from this definition because they lack these traits.

Each proposal is plausible, but neither is altogether satisfying. The first definition does not explain why genetic humanity is a inorally significant quality for endowing an entity with personhood rights. Genetic humanity may be morally relevant to personhood, but to start with that assumption appears to be mere "speciesism."72 Moreover, possessing potential or eventual personhood is not the sane as possessing actual personhood, and the rights of potential persons are not necessarily those of actual persons.

The second definition has inore moral significance in that it probably describes more accurately our notion of the necessary as well as the sufficient qualities of those entities we consider to have personhood rights. Although this definition excludes fetuses, it also excludes new-

68. See infra text accompanying notes 70-71.

69. See, e.g., Noonan, An Almost Absolute Value in History, in THE MORALITY OF ABORTION: Legal AND Historical Perspectives 51, 55-58 (J. Noonan ed. 1970) (rejecting distinctions based on viability and visibility, experience and feeling: a being conceived by human parents is a person from the moment of conception); Feimberg, Abortion, in MATTERS OF LIFE AND DEATH 183 (T. Regan ed. 1980) (arguing that although the fetus is obviously human in the genetic sense, it is not a person in the moral sense); Gardner, Is an Embryo a Person?, 249 Nation 557 (1989) (asserting a fundamental difference between an embryo and a human being); Meilaender, Abortion: The Right to an Angument, HASTINGS CENTER REP., Nov.-Dec. 1989, at 13 (asserting that moral puzzles will not be resolved by resort to compromise positions: a "middle position" in the arguinent over abortion is itself a substantive moral position); Strasser, Noonan on Contraception and Abortion, 1 BioETHICs 199 (1987) (rejecting Noonan's reasoring); Tooley, Abortion and Infanticide, in THE ETHICs of ABORTION 45 (R. Baird \& S. Rosenbaum eds. 1989) (concluding that neither fetuses nor infants are people in the inoral sense); Warnock, Do Human Cells Have Rights?, 1 BIOETHICs 1 (1987) (research using human embryos should be allowed to continue, but human cells are not to be used frivolously or for no good end); Warren, On the Moral and Legal Status of Abortion, 57 MoN15T 43 (1973) (neither a fetus' resemblance to a person nor its potential for becoming a person means that it is a person in the moral sense).

70. Noonan, supra note 69 , at 57.

71. Feinberg, supra note 69, at 188-89; see Warren, supra note 69 , at 55.

72. That is, the assumption that a person in the moral sense is a genetic human, without recognizing that other species may also fit the definition of inoral personhood. 
born babies, which have little ability to reason or make future plans. Few would agree with this result. ${ }^{73}$

The law also reflects the unclear moral status of the fetus by giving it the rights of a person in some areas but not in others. As discussed above, the fetus has fewer rights in the areas of property, criminal, and tort law than do ordinary persons. ${ }^{74}$ Thus, fetuses are not persons for purposes of inheriting property, punishing their wrongdoers, or collecting damages in case of their wrongful injury or death. Some courts have found that laws protecting children from neglect do not extend to fetuses. ${ }^{75}$ Other courts have found these laws applicable to fetuses, making the child a ward of the court to protect it from neglect or abuse. ${ }^{76}$ In the abortion context, the Supreme Court lias found that a fetus is not a person for purposes of the fourteenth amendment. ${ }^{77}$

Because different legal contexts differ on whether the fetus is considered a person, it is not immediately clear what legal status the fetus should have in the fetal surgery context. Since it seems impossible to determine whetlier the fetus lias or sliould liave the riglits of a person, it inay be inore useful to look at the problem froin another perspectivethat of maternal duty ratlier tlian of fetal rights. That is, we should examine wliether, even assuming for the sake of discussion that the fetus has full personhood riglits, we can impose a duty on the pregnant woman to undergo surgery for the fetus' sake. To inake this determination, we will examine inore closely the doctrine of informed consent and its underlying values.

\section{IV \\ Maternal Rights AND DUTIES \\ A. The Informed Consent Doctrine}

Under the doctrine of informed consent, a doctor owes a duty to the patient of reasonable disclosure of infornation about a recoinmended procedure-including the risks of undergoing ${ }^{78}$ and of not undergoing

73. But see Tooley, supra note 69 (author does espouse this idea).

74. See supra notes 9-11 and accompanying text.

75. See, eg., Matter of Steven S., 126 Cal. App. 3d 23, 29-30, 178 Cal. Rptr. 525, 527 (1981) (fetus is not a "person" under statute defining persons whom juvenile court may make wards of the court); Reyes v. Superior Court, 75 Cal. App. 3d 214, 219, 141 Cal. Rptr. 912, 915 (1977) (statute relating to felony child endangerment did not refer to fetus).

76. See, e.g., Hoener v. Bertinato, 67 N.J. Super. 517, 524-25, 171 A.2d 140, 144-45 (1961) (unborn child has rights to life and health that are entitled to legal protection even though child is not viable); Jefferson v. Griffin Spalding County Hosp. Auth., 247 Ga. 86, 88, 274 S.E.2d 457, 459 (1981) (unborn child was "deprived child" not given proper parental care for physical health).

77. Roe v. Wade, 410 U.S. 113, 158 (1973).

78. See, e.g., Canterbury v. Spence, 464 F.2d 772, 782 (D.C. Cir.) ("It is well established that the physician must seek and secure his patient's consent before commencing an operation or other course of treatment . . . "), cert. denied, 409 U.S. 1064 (1972); Cobbs v. Grant, 8 Cal. 3d 229, 243, 
the procedure ${ }^{79}$ - that would be material to the patient's decision about whether or not to consent to treatment. Once the patient has been told the necessary information, if she is competent to make a decision, she must consent before the proposed treatment can begin. If she does not make a choice or if she refuses the treatment, a doctor may not undertake the treatment. ${ }^{80}$

Although the doctor may be more knowledgeable about the patient's condition and the risks and benefits of the proposed treatment, the doctor may not make the choice for the patient. The patient is more capable than the doctor of weighing within the patient's value system the prospect of undergoing the treatment. ${ }^{81}$ As Benjamin Cardozo said in 1914, "Every human being of adult years and sound mind has a right to determine what shall be done with his own body; and a surgeon who performs an operation without his patient's consent commits an assault, for which he is hable in damages." ${ }^{82}$ Thus, if a woman has been fully informed about a proposed operation, is competent to make a decision, and has refused the procedure, then to override her refusal and perform the surgery against her will would be contrary to the informed consent doctrine. ${ }^{83}$

In a few situations, howevcr, informed consent procedures, or even

502 P.2d 1, 10, 104 Cal. Rptr. 505, 514 (1972) (doctor must provide reasonable disclosure of available choices with respect to proposed therapy, and dangers inherently and potentially involved in each); Natanson v. Kline, 186 Kan. 393, 409-10, 350 P.2d 1093, 1106 (1960) (doctor must disclose those consequences of treatment that a reasonable doctor would disclose under the same or similar circumstances).

79. See, e.g., Truman v. Thomas, 27 Cal. 3d 285, 292, 611 P.2d 902, 906, 165 Cal. Rptr. 308, 312 (1980) (patient must be informed not only of risks inherent in procedure but also of risks of decision not to undergo treatment).

80. See, e.g., Schlocndorff v. Society of N.Y. Hosp., 211 N.Y. 125, 129-30, 105 N.E. 92,93 (1914) (surgeon performing operation without patient's consent commits an assault, except in emergency cases where patient is unconscious and must be operated on before conscnt can be obtained).

81. See Shultz, From Informed Consent to Patient Choice: A New Protected Interest, 95 YAlE L.J. 219, $270-72$ (1985) (choosing among alternative courses of action implicates individual characteristics of the patient, such as personal attitudes and values ranging from religious belief to risk-aversion).

82. Schloendorff, 211 N.Y. at 129-30, 105 N.E. at 93 . The doctrine of informed consent is based on the common law prohibition against battery, the intentional unauthorized touching of one person by another. Thus, the doctor's right to exercise her autonomy by touching the patient is limited by the restriction against harming others or infringing their rights. If the paticnt consents to the touching, however, there has been no harm. In the surgery context, conscnt is a critical element in determining whether the touching is harmful and thus constitutes an assault.

83. It should be noted that the informed consent doctrine does not provide complete patient self-determination or autonomy, for the patient only has a right to refuse proposed treatment or to choose between treatment options. The patient has no right under this doctrine to insist on treatment the doctor is unwilling to perform. Indeed, the doctor, by selecting which options to present to the patient, may in fact have more power over patient decisionmaking than the doctrine would seem to indicate. But at the least, the doctrine provides the patient with the power of final refusal. 
the patient's decision, may be set aside. The first occurs where the patient is imcompetent to make a decision about her treatment. ${ }^{84}$ In that situation, paternalistic intervention to decide what is best for the patient may well be justified. ${ }^{85}$ But the woman's competence has not been at issue in the forced cesarean cases, nor should it be in the forced fetal surgery situation-unless we are willing to assume that choosing not to help one's fetus when given the option of undergoing fetal surgery proves one's incompetence. Most people would be unwilling to make that assumption.

The second situation in which a patient's decision may be set aside occurs if the patient consents to (or refuses) a procedure, but would not have done so had the doctor adequately informed her about the risks of undergoing it (or of not undergoing it). ${ }^{86}$ But this situation would not be likely to arise with the refusal of fetal surgery because neither the pregnant woinan nor her doctor would wish to challenge her refusal of surgery. ${ }^{87}$

In a third situation, on public policy grounds, courts can override

84. See, e.g., Department of Human Servs. v. Northern, 563 S.W.2d 197, 209-10 (Tenn. Ct. App. 1978) (patient's gangrenous feet permitted to be amputated after she was deemed imcompetent to understand her condition or to consent to treatment). This category also imcludes emergency situations where the patient requires treatment immediately but is unconscious and therefore incompetent to make a decision about her health care.

85. Many courts now use the mechanism of "substituted judgment" to determine what treatment the mentally imcompetent patient herself would have preferred were she competent. See, e.g., Cruzan v. Director, Missouri Dep't of Health, 110 S. Ct. 2841, 2854-56 (1990) (due process clause does not require a state to accept the substituted judgment of close family members in the absence of substantial proof that their views reflect the patient's). The choice inay not necessarily be the same as what the court, doctor, or family would do, were they to decide in the patient's best imterests. See, e.g., Superintendent of Belchertown State School v. Saikewicz, 373 Mass. 728, 750-51, 370 N.E.2d 417, 431 (1977) (when determining whether potentially life-prolonging medieal treatment should be given to terminally ill, mentally incompetent patient in state institution, court should apply "substituted judgment" doctrine, and decision should be what incompetent person would choose if competent; this may or may not conform to what is thought wise or prudent by most people); see also In re Quinlan, 70 N.J. 10, 41-42, 355 A.2d 647, 664 (allowing father, as guardian of patient in persistent vegetative state, to assert patient's right of privacy and permitting withdrawal of life support system against doctors' recommendation), cert. denied, 429 U.S. 922 (1976).

86. See, e.g., Canterbury v. Spence, 464 F.2d 772, 786 (D.C. Cir.) (doctor is hable ouly if his "communication was unreasonably inadequate"), cert. denied, 409 U.S. 1064 (1972); Cobbs v. Grant, 8 Cal. 3d 229, 245, 502 P.2d 1, 11, 104 Cal. Rptr. 505, 515 (1972) (for patient to recover in malpractice action on theory of lack of informed consent, there must be causal counection between doctor's failure to disclose and patient's injury; such connection arises only if it is established that, had doctor provided sufficient information, patient would not have consented to treatment); Natanson v. Kline, $186 \mathrm{Kan} .393,406,350$ P.2d 1093, 1103 (1960) (if doctor fails to disclose consequences of treatment that a reasonable doctor would disclose under the same or similar circuinstances, doctor may be hable for unauthorized treatment).

87. The pregnant woman who is trying to avoid surgery does not want her refusal invalidated. She would not, therefore, charge that her refusal was uninforned. Likewise, the doctor would not want her refusal invalidated on the grounds of having disclosed inadequate infornation. If the doctor had already performed the treatment, invalidating the patient's consent on this basis would make the doctor liable for malpractice; if the doctor had not yet performed the treatment, 
for the sake of the patient's health her competent and informed refusal of treatment. ${ }^{88}$ Although the state's interest in the patient's health might allow overriding her refusal of a cesarean section (if refusing would endanger her health), ${ }^{89}$ the woman's health is not in any way endangered by her refusal of treatment in the fetal surgery context. In fact, she endangers her health more by agreeing to undergo surgery on behalf of the fetus than by refusing. Thus, since these public policy reasons are aimed solely at furtliering the state's interest in preserving the health of the patient who refuses treatment, they do not apply to the fetal surgery context.

A final reason for overriding the woman's informed, coinpetent refusal rests on the fundamental value underlying the doctrine: autonomy. ${ }^{90}$ We will next examine this value and the factors that linit its force to determine whether they can be applied im the fetal surgery context to limit the doctrime of informed consent.

\section{B. The Underlying Autonomy Principle}

Autonomy comes from the Greek words autos, meaning "self," and nomos, meaning "rule" or "law." As As Gerald Dworkin writes, "Our idea of who we are, of our self-identity, is linked to our ability to find and refine ourselves. The exercise of the capacity of autonomy is what makes my life mine." found, "Self-determination as a shield is valued for the freedom from outside control it is intended to provide. It manifests the wisls to be an

invalidating the patient's consent on the basis of inadequate disclosure would be curable by further disclosure and subsequent patient consent.

The situation allowing for setting aside the wounan's decision on this basis could arise if the woinan agrees to the surgery but would have refused had she been given adequate information. But cf. infra notes 181-87 and accoinpanying text. That is not the issue here. It is conceivable, however, that cases could be brought by outsiders on behalf of the fetus, alleging that if the pregnant woinan had known the actual effect on the fetus of her refusal, she would not have refused. Presumably this charge could be countered by testimony from the woman that she either was adequately informed by her doctor or that even if shc had been her decision would not have been different.

88. The most frequently cited rcasons are the state's interests in preserving the patient's life, protecting third parties who are dependent on her, preventing suicide, and maintaining the ethical integrity of the medical profession. Saikewicz, 373 Mass. at 741,370 N.E.2d at 425 . These reasons, however, only justify protecting the patient's health-never a third party's. Thus, for example, the state could not justify overriding a inother's refusal to donate an organ to save her child's life, although it might justify forcing her to accept an organ transplant to save her own.

89. In the cesarean section context, the woman's health and life inay be endangered by her refusal of surgery. See, e.g., supra note 63 (discussing placenta previa); see also supra note 50.

90. But cf. supra note 82 .

91. Dworkin, Autonomy and Informed Consent, in President's Commission for the Study of Ethical Problems in Medicine and Biomedical and Behavioral Research, 3 Making Health CaRe Decisions: The EThical and Legal Implications of Informed CONSENT IN THE PATIENT-PRACTITIONER RELATIONShip 63, 70 (1982).

92. Id. at 73 (emphasis in original). 
instrument of one's own and 'not of other men's acts of will." "93

In recent years, some scholars have criticized the position that autonomy is the supreme social value. Some argue that the hands-off approach is not or should not be enough to bind a society. To them, a society's very survival requires intervention in the hives of its members to enforce the society's shared morality. ${ }^{94}$ While this may hold true in the social context, in the world of doctor and patient, autonomy-as embodied in the inforined consent doctrine-is still the dominant and evergrowing value. ${ }^{95}$ Yet even autonomy has its limits.

\section{Limits to Autonomy: Harm to Others}

Ordinarily, an individual can act, make choices, and control her life without interference by others or the state. She does not, however, have unlimited freedom to act as she wishes if so acting will harm another person's interests or interfere with his rights, for example, by shooting him, driving through his prize begonias, or stealing his money. Nor does she have an unlimited right to act as she wishes if doing so will harm the interests of society generally, for example, by polluting the atmosphere. Society may place restrictions on her autonomy in those situations where the free exercise of autonomy without limits would harm others. As John Stuart Mill says:

As soon as any part of a person's conduct affects prejudicially the interests of others, society has jurisdiction over it, and the question whether the general welfare will or will not be promoted by interfering with it becoines open to discussion. But there is no rooln for entertaining any such question when a person's conduct affects the interests of no persons besides himself .... It is far otherwise if he has infringed the rules necessary for the protection of his fellow creatures, individually or collectively.

93. President's Commission for the Study of Ethical Problems in Medicine and Biomedical and Behavioral Research, 1 Making Health Care Decisions: The EThical AND Legal IMPlications of INFormed CONSENT IN THE Patient-Practitioner RELATIONSHIP 45-46 (1982) (quoting Berlin, Two Concepts of Liberty, in FoUR ESSAYS ON LIBERTY 118-38 (1969)). "As a sword, self-determination manifests the value that Western culture places on each persou having the freedom to be a creator-'a subject not an object." 'Id. at 46 (quoting Berlin, supra, at 118-38). The Commission finds that "[i]f people have been able to form their own values and goals, are free from manipulation, and are aware of information relevant to the decision at hand, the final aspect of self-determination is simply the awareness that the choice is their own to make." Id.

94. See, e.g., P. Devlin, Mill on Liberty in Morals, in The EnforCeMent of Morals 103, 105 (1965) (arguing that although the great majority of our fellow citizens may be as high-minded as Mill expected them to be, "we have not yet got rid of the troublesome minority who will yield only to compulsion"); P. DEvin, Morals and Contemporary Social Reality, in THE ENFORCEMENT of MORAls, supra, at 124 (explaining Professor Hart's exceptions to Mill's doctrines).

95. Even Jay Katz, who denounces the informed consent doctrine as nothing inore than "a mirage," recognizes that the doctrine is new, relative to the hundreds of years of quite contrary doctor-patient practice preceding it, and it will therefore take time for long-ingranied habits to change. See J. Katz, The Silent World of Doctor and Patient 60, 84 (1984). 
The evil consequences of his acts do not then fall on himself, but on others; and society, as the protector of all its members, must retaliate on him. ${ }^{96}$

Society may justifiably prevent someone from harming another, and society may also punish someone for having harmed another. This is a legitimate and necessary curtailment of each person's autonomy. The next two Sections explore whether refusing to undergo surgery for the sake of the fetus is an action we may justifiably prohibit as a legitimate curtailment of autonomy.

\section{Harming the Fetus: Negative Duties}

Society regards negative duties, which require restraining one's actions to avoid harming others, as justifiable curtailments of autonomy. Affirmative duties, by contrast, which typically require one to aid others, rarely justifiably limit autonomy. If we consider a pregnant woman's refusal of treatment to be harming another person-namely, the fetus $^{97}$-her right to autonomously refuse could justifiably be curtailed. If, on the other hand, the woman's refusal is not considered harm but simply failing to aid, ${ }^{98}$ curtailing her autonomy becomes of questionable legitimacy.

It is hard to accept the idea that refusal to aid is morally justifiable. After all, if an Olympic swimmer could, with very little effort, save a person from drowning in three feet of water, ${ }^{99}$ how can we say she has no moral duty to act? Does the swimmer not deserve our moral condemnation for sitting nearby, doimg nothing but histenimg to the drowming person's screams?

In a utilitarian inoral scheme, the best outcome requires the swimmer to exert a little energy to rescue the drowning person. The person drowning receives a great benefit, with minimal imposition on the swimmer. In a deontological or rights-based framework, ${ }^{100}$ however, it is

96. J. Mill, On Liberty, in UtILITARIANISM, LIBERTY, AND REPRESENTATIVE GOVERNMENT 132-36 (1948).

97. I am assuining, for the inoinent, that a fetus is a person and therefore inportant enough to justify curtailing a woinan's autonoiny right to inake her own health care decisions. See supra text accompanying notes 67-77.

98. See Foot, The Problem of Abortion and the Doctrine of the Double Effect, in KILL1NG AND LETTING DIE 156, 162-64 (B. Steimbock ed., 1980) (underhining the importance of the "distinction between avoiding injury and bringing aid").

99. W. Keeton, D. Dobes, R. Keeton \& D. OWen, Prosser \& Keeton on The LAW of TORTs $§ 56$, at 375 (5th ed. 1984) [hereinafter Prosser \& KeETON] ("The expert swimmer, with a boat and a rope at hand, who sees another drowning before his eyes, is not required to do anything at all about it, but may sit on the dock, sinoke his cigarette, and watch the man drown.").

100. At law, this hypothetical is in fact governed by a deontological mle, as reflected in the Restatement: "The fact that the actor rcalizes or should realize that action on his part is necessary for another's aid or protection does not of itself inpose upon hin a duty to take such action." RESTATEMENT (SECOND) OF TORTS $\$ 314$ (1965). Section 314 eomment c elaborates, "The rule 
morally wrong to curtail the swimmer's autonomy by forcing her to take action, yet morally neutral to allow the person in the water to drown and the swimmer to act as she pleases. The reason for this is that the swimmer is not harming the drowning person (that is, restraining the swimmer's actions will in no way avoid the drowning person's harm); she is not the cause of his misery; ${ }^{101}$ nor is she making his predicament worse than it would be if she were nowhere near the scene. ${ }^{102}$ Of course, the swimmer is completely unjustified if she jumps in and holds the drowning person's head under water. Doing so harms the drowning person, either by hastening his death or by preventing others from rescuing him.

In the pregnancy context, the deontological model requires the pregnant woman to refrain from doing anything that would harm her fetus or exacerbate its already unhealthy condition. Thus, she could be prevented from (or puirished for) smoking, ${ }^{103}$ drinking alcohol, ${ }^{104}$ taking drugs, ${ }^{105}$ or engaging in strenuous activity ${ }^{106}$ that would harm the fetus. ${ }^{107}$ But, as

stated in this Section is applicable irrespective of the gravity of the danger to which the other is subjected and the insignificance of the trouble, effort, or expense of giving him aid or protection." Id. $\$ 314$ comment $\mathrm{c}$.

101. That the drowning person's harm is not caused by the Olympian bystander but rather by natural forces or an evil third person is significant in the rights-based moral framework. See Rhoden, supra note 4, at 2002 n.266 (citing C. FRIED, RIGHT AND WrONG 2, 73 (1978)); Thomson, The Trolley Problem, 94 YALE L.J. 1395, 1406-15 (1985); Williams, A Critique of Utilitarianism, in UTILITARIANISM: FOR AND AGAINST 77, 99 (1973); see also infra text accompanying note 120.

102. See infra text accompanying notes 115-19.

103. Sunoking during pregnancy can lead to preinature delivery and low birth weight. Goldberg, Medical Choices During Pregnancy: Whose Decision Is It Anyway?, 41 RUTGers L. REv. 591, 602 n.83 (1989) (citing Shino, Klebanoff \& Rhoads, Smoking and Drinking During Pregnancy: Their Effects on Preterm Birth, 255 J. A.M.A. 82, 84 (1986)).

104. Drinking even small amounts of alcoliol during pregnancy can retard the fetus' growth, and drinking large amounts can cause fetal alcolol syndrome, a condition that stunts the fetus' growth, damages its central nervous system, and deforms its face. Goldberg, supra note 103, at 602 n.82.

105. See, e.g., Grodin v. Grodin, 102 Micl. App. 396, 301 N.w.2d 869 (1980) (finding that a child lad a cause of action in tort against his mother for his discolored teetl, caused by the tetracycline slie took while pregnant).

106. See, e.g., Pcople v. Stewart, No. M508197 (San Diego Mun. Ct. Feb. 23, 1987). Pamela Rae Stewart was indicted on September 26, 1986, for the massive brain damage and subsequent death of her newborn son, allegedly caused by her disobeying a doctor's order to, among other things, refrain from having sexual intercourse with her husband while pregnant. The charges were dropped, but not before the media sprcad her name and details of her private behavior across the nation. See G. ANNAS, supra note 4, at 93-95; Gallaglier, supra note 4, at 45; Johnsen, $A$ New Threat to Pregnant Women's Autonomy, Hastings CeNTER REP., Aug. 1987, at 33; Woman Is Acquitted in Test of Obligation to an Unborn Child, L.A. Times, Feb. 27, 1987, pt. I, at 3, col. 3.

107. The extent of intervention that is appropriate is another question entirely. Punishing the woman, whether by damages or criminal sanctions, for liaving liarmed a fetus may be far less imtrusive or constitutionally suspect than preventing the woman from causing the fetus larmwhich might require curtailing ler biberty. The latter actually occurred in United States v. Vaughn, Crim. No. F 2172-88 B (D.C. Super. Ct. 1988), in which pregnant Brenda Vauglin pleaded gnilty to check forging but, rather than imposing the recommended probation, the judge sentenced her to prison for the duration of her pregnancy for the sake of her fetns, because she liad tested positive for cocaine. Johnsen, From Driving to Drugs: Governmental Regulation of Pregnant Women's Lives 
with the swimmer, restraining the pregnant woman's actions is not at issue in the fetal surgery context, since her actions do not cause the conditions for which fetal surgery is an appropriate treatment, ${ }^{108}$ nor is it apparent that her actions can be restrained im any way that will stop the fetus' harm.

But what action on the woman's part causes affirmative harm? As noted above, inuch that a woinan inay do that harms a fetus is not in itself illegal or even very harmful to anyone, not even to the woman herself. Drinking a glass of wine each might is hardly thought of as harmful. Likewise, exercising is generally considered healthful. Yet, to the highly sensitive fetus, both of those activities could cause great harm. In one case, a woman who adhered strictly to a macrobiotic diet was found to be a danger to the child she was breastfeeding as well as to any fetus she might carry. ${ }^{109}$ While a macrobiotic diet may be so extreme as to be obviously harmful, at what less extrene point do we draw the lime? Indeed, there may always be some shightly better behavior a pregnant woinan could have engaged in to inflict less "harm" on her fetus.

At the other extreme, there are many acts of aid that a woman may not already engage in that are necessary for the fetus' health. These include taking vitamins and eatimg enough. If a wolnan were impoverished or merely neglectful of her own health, she could also endanger the health of her fetus. If there were a decrease in the woman's level of nutrition during pregnancy, the fetus' condition would worsen and thus she would be harming it. But is there no harin when the woman decides to stop taking vitamins and start a starvation diet a few days before the fetus' conception? In this case, it is true, the fetus itself suffers no worsening of condition. But, as with the macrobiotic diet, is this behavior on the woman's part not equivalent to harm? It is difficult to distinguish these situations. In the next Section, we address the following questions: Under what conditions will we impose affirmative duties on the pregnant woman to aid her fetus? Under what conditions will we require the Olyınpic swimmer to rescue the drowning person?

After Webster, 138 U. PA. L. REv. 179, 194 n.52 (1989); Goldberg, supra note 103, at 602 n.88. Of course, many, if not most, of a woman's activities or behaviors that cause harm to the fetus are not in themselves illegal. It would be problematic to punish a woman for smoking cigarettes before learning she was pregnant, although such behavior may have damaged the fetus.

108. See infra text accompanying note 120 .

109. People v. Pointer, 151 Cal. App. 3d 1128, 199 Cal. Rptr. 357 (1984). Although her probation condition that she not become pregnant at all was overturned, the Court of Appeal held that were she to become pregnant during the probationary period, she could be required "to follow an intensive prenatal and neonatal treatment program monitored by both the probation officer and by a supervising physician." Id. at $1140,199 \mathrm{Cal}$. Rptr. at 365 . She would thus be unable to follow her macrobiotic diet. 


\section{E. Aiding the Fetus: Affirmative Duties and Special Relationships}

Affirmative duties are rare in our society. Based on principles of personal autonoiny and self-determination, our law almost never requires a person to be a Good Samaritan. Although the law limits our ability to do harm to another, it rarely imposes the affirmative duty to give aid to another who is in need. ${ }^{110}$

The usual case cited for this proposition is McFall v. Shimp, ${ }^{111}$ in which a inan suffering from a rare and terminal bone marrow disease petitioned a court of equity to compel his first cousin, the only person he could find who was a compatible marrow donor and who had refused to undergo the procedure, to submit to bone marrow extraction for transplantation. ${ }^{112}$ Although the extraction of bone marrow is only somewhat intrusive and painful to the donor and although the transplant was the plaimtiff's last hope, the court, in proper deontological manner, refused to compel the reluctant cousin to submit to the invasive procedure for the patient's benefit. It stated: "For a society which respects the rights of one individual, to sink its teeth into the jugular vein or neck of one of its inembers and suck froin it sustenance for another member, is revolting to our hard-wrought concepts of jurisprudence."113 If this principle were applied to all members of society, no woinan could be compelled to undergo fetal surgery for the benefit of her fetus.

Although generally the only limit on a person's autonomy is the negative duty to refram froin harming others, society does impose affirmative obhigations to act in certain ways in a few situations. The most obvious is perhaps the contract. In a typical contract, two people undertake to perform in certam ways. For example, we may agree that if you will mow my lawn, I will pay you five dollars. Once you finish mowing the lawn, the law imposes on me an affirmative duty to pay you the agreed sum. Clearly, though, no affirmative contractual duty arises in the ordinary pregnancy. ${ }^{114}$

Other common situations involving affirmative duties arise because the act of harming another generates a corresponding duty to aid. These

110. See generally Regan, Rewriting Roe v. Wade, 77 Mich. L. REv. 1569, 1569-70 (1979) (defending abortion by viewing pregnancy as an act of Samaritanism); Nelson, Bnggy \& Weil, supra note 4 (condemming forced prenatal treatment generally); Rhoden, supra note 4 (applying the "Bad Samaritan" principle and condemning the requirement that a woman nndergo cesarean section to aid her fetus). The Bad Samaritan model was also used in the recent overturning of a forced cesarean case in In re A.C., 573 A.2d 1235 (D.C. 1990). The court held that the woman's wishes must prevail in all cesarean section cases; if she is incompetent to give informed consent or refusal, judgment will be substituted on her behalf. Id. at 1237 .

111. 10 Pa. D. \& C.3d 90 (Allegheny Connty Ct. 1978).

112. Id. at $90-91$.

113. Id. at 92 (emphasis added).

114. Their legality aside, contracts for surrogate pregnancy may well imclude terms controlling what behaviors the pregnant woman must and must not engage in. 
situations are illustrated by the law of torts, which requires aid to prevent harm where one's actions have created the risk of harm to another ${ }^{115}$ and to prevent further harm where one's actions have caused harm to another and left her defenseless. ${ }^{116}$ Furthermore, tort law prohibits ceasing to aid once one has begun to aid another, ${ }^{117}$ requires giving aid to one who is helpless of whom one has taken charge, ${ }^{118}$ and prohibits preventing others from giving aid where they are willing to do so. ${ }^{119}$

One may argue that because the woman caused (or presunably only half-caused) the fetus to exist, she is responsible for the harm it now suffers. While she may not have intended to harm the fetus, she engaged in the voluntary act of sexual intercourse that caused the fetus to exist: but for that act, the fetus would not be suffering. But I would argue that natural forces caused the genetic breakdown that led to hydrocephalus and therefore were an unforeseeable, intervening cause. Thus, although the woman may have been the "but for" cause of the fetus' harm, she is not its proximate cause and is therefore not responsible for the harm. ${ }^{120}$ Thus she would not be required to take any affirmative action to aid the fetus, such as having a transfusion, having a cesarean, or undergoing fetal surgery to try to remedy its condition. She would not even be required to take vitamin suppleinents for the benefit of the fetus if she does not norinally take them.

Affirmative duties also arise in "special" relationships. ${ }^{121}$ These are

115. RESTATEMENT (SECOND) OF TORTS § 321 (1965).

116. Id. § 322 .

117. Id. $\S 323(\mathrm{~b})$.

118. Id. § 324 .

119. Id. $\S 326$. These requirements to aid result from the actions of the person in the dominant position, rather than from the inherently special nature of her relationship to the dependent one. In none of the above situations (all of which potentially apply to a pregnant woman and her fetus requiring prenatal surgery) would the law require the dominant person to exercise more than "due care" to ensure the safety of the helpless one. Cf. infra notes 131-33 and accompanying text.

120. See generally PROSSER \& KEETON, supra note 99, $\S 44$ (discussing the requirement of proximate cause). If the reason for holding someone hable in negligence is to penalize her for failing to take adequate precautions against the result that occurred, it is obvious that even the most careful woinan engaging in sexual intercourse could not guard against hydrocephalus. She could, of course, use birth control to guard against producing any fetus, but presunably the law would not require her to avoid having children. Sexual intercourse cannot, therefore, be an inherently negligent act.

I do not know whether parents would have a duty to avoid having children if they were informed they had a significant chance of producing a hydrocephalic baby. Perhaps the parents would be permitted to take the chance if the woinan were willing to abort or seek fetal surgery should the fetus in fact prove hydroccphalic. Currently, however, a woman is not required to abort should her fetus prove to have Tay-Sachs disease, even if she knew before becoming pregnant of a significant likelihood of passing the disease on to her fetus. This result seeins consistent both with the autonoiny principle and the constitutional protection of "individual decisions in inatters of childbearing from unjustified intrusion by the States." Carey v. Population Servs. Int'l, 431 U.S. 678, 687 (1978).

121. Examples of these relationships recognized at law include innkeeper-guest, employcreinployee, teacher-student, and jailor-prisoner. RESTATEMENT (SECOND) OF TORTS § 314A (1965). 
relationships in which one person is dependent on another who is in a position of dominance or power to aid. Often, as in the cases of innkeepers, shop owners, bus companies, and theater owners, the dominant person gets some benefit or profit by taking in the dependent person. In return, we impose on her a special responsibility to aid or protect him.

In other cases, as with school teachers, babysitters, doctors, firefighters, lifeguards, and parents, the dominant person has voluntarily taken charge (or has taken a job that puts her in charge) of someone she knows or should know to be dependent on her, and the dominant person is in a unique position to help him. These special relationships require the dominant person to protect the dependent person or persons "against unreasonable risk of physical harm, and . . to give them first aid after [she] knows or has reason to know that they are ill or mjured, and to care for them until they can be cared for by others."122 Thus our Olympic swimmer has a duty to rescue the drowning person only if the swimmer is at the time, for example, babysitting him or acting as a lifeguard.

Likewise, a nother has a duty to seek medical help for her sick child. ${ }^{123}$ As indicated earlier, states vary on whether their juvenile neglect statutes apply to fetuses. ${ }^{124}$ But assuming for the sake of argument that a fetus is a child (or put another way, assuming that a motherfetus relationship should be recognized as special), ${ }^{125}$ one might conclude that a woman would have an affirmative duty to aid her fetus by seeking any medical help necessary for its health-including fetal surgery. Thus, unlike the $\mathrm{McF}$ all case, ${ }^{126}$ where the parties were merely first cousins and not in a recognized special relationship, in a recognized mother-fetus special relationship, the woman could be required to undergo a surgical procedure for the benefit of the fetus. ${ }^{127}$

122. Id. § 314A(1)(a), (b).

123. Child neglect statutes, based on the special parent-child relationship, impose this affirmative duty on a parent. See, e.g., CAL. PENAL CODE $\$ 270$ (West 1988) (parent's failure to seek medical care for child without lawful excuse is a crime); NEV. REV. STAT. § 201.090(3) (1986) (neglected child is a person under 18 years of age whose parents do not provide it with necessities of life); see also Nelson, Buggy \& Weil, supra note 4, at 725-29 (discussing the application of child neglect statutes in cases of maternal-fetal conflict).

124. See supra notes $\mathbf{7 5 - 7 6}$ and accompanying text.

125. Of course, the existence of legal abortion indicates that society recognizes no special relationship in this context. Most fetal rights advocates agree that because of the existence of abortion as an option, any mother-fetus special relationship would arise only once the woman's legal option of abortion is foreclosed, typically at fetal viability. See supra notes 48-61 and accompanying text. But given the option of placing a baby up for adoption at birth, one could argue that the mother-offspring special relationship begins when the woman has decided to kecp the baby after birth.

126. See supra notes 111-13 and accompanying text (discussing McFall).

127. Many authors take $M c F a l l$ to mean that one person is never required to undergo a bodily invasion for the benefit of another. See Nelson, Buggy \& Weil, supra note 4, at 755. This conclusion does not take account of incompetence, see infra note 137, or special relationships. 
Several factors both support and undercut this conclusion. They are probably best illustrated by comparing the fetal surgery situation to other special relationship situations, particularly to the situation in which a parent's kidney is needed to save the life of a child. While most parents would voluntarily donate the kidney to their child in need, just as most pregnant women would willingly undergo surgery to save their fetuses, it is doubtful that a court would compel a parent to donate the kidney. Donald Regan has written:

It would be interesting to see a case in which the issue was presented of whether a parent has a duty to donate a needed organ to his or her child. My guess is no duty would be found. . . . Donating a kidney ordinarily has no effect at all so long as the other kidney reinains intact. Donating bone marrow has only teinporary effects [for the donor], since the bone marrow regenerates. I would be surprised if any American court ordered even a parent-to-child bone-marrow transplant. . . . 128

Although a parent-child special relationship would not impose on the parent an affirmative duty to undergo a surgical procedure for the benefit of the child, there may be significant differences between the parent-child situation and the mother-fetus situation that would justify imposing a more stringent duty in the latter.

The significant difference is that in the fetal surgery context, the pregnant wonian is in a unique position to help the fetus. No one can possibly undergo the surgery but the wonan. Because the fetus is inside the wonian, ouly she, given the current state of medical technology, can offer the fetus the aid it needs. On the other hand, in the parent-child organ or bone marrow donation situation, although one who is in the special relationship with the unhealthy child has a greater chance of being compatible (by virtue of being closely related), that does not mean it is impossible to find another suitable donor. Thus, although a parent may be in an uncommon position to help the child, it is not a unique position. This factor would warrant a more stringent duty in the motherfetus context than in the parent-child context.

Weighing against a more stringent maternal-fetal duty, however, is the factor of risk or burden to the doninant person in the special relationship. In all special relationships, we impose sonte burden on the dommant person by requiring her to take affirmative action to aid the dependent in need. Thus, the departinent store owner is required to push a button to stop the escalator that has trapped the shopper. ${ }^{129}$ Likewise, if a patient reveals to his psychiatrist the nanie of his intended nuurder

128. Regan, supra note 110 , at 1586 .

129. RESTATEMENT (SECOND) OF TORTS $§ 314$ A comment f, illustration 4 (1965). 
victim, the doctor must warn the intended victim. ${ }^{130}$ Granted, requiring soineone to aid imposes more of a burden than not requiring the person to do anything. The special relationship, however, does not require the rescuer to put herself at risk dehivering aid. ${ }^{131}$ Indeed, most commentators agree that the relationship imposes only a duty of reasonable or due care and nothing more. ${ }^{132}$

Even the parental duty to seek medical help for one's child ${ }^{133}$ imposes far less burden and risk on the dominant party than does the duty proposed for the pregnant woman. In the parent-child relationship, seeking medical help for the child imposes minimal burdens and risks on the parent. Even in serious medical situations, the parent's duty entails calling a doctor or taking the child to a doctor or emergency rooin and allowing the child to be treated. For some parents, this may be a heavier burden in terins of finances and social stigma than for others. But the parent at no time suffers a bodily intrusion to help the child. In the mother-fetus relationship, however, any time the fetus needs medical aid, the woinan must undergo a bodily intrusion. Even if the fetus can be treated with vitamins, the woman has to swallow them before they can help.

Although many women inay willingly accept the risks and physical intrusions inherent in fetal surgery, soine women will not agree to such intrusions into their bodies. Such a nonconsensual intrusion is physical, but it may also violate the woinan's rehgious precepts, ${ }^{134}$ einotional

130. Tarasoff v. Regents of Univ. of Cal., $17 \mathrm{Cal} .3 \mathrm{~d} 425,431,551 \mathrm{P.2d} 334,345-46,131 \mathrm{Cal}$. Rptr. 14, 20 (1976).

131. The rescuer "is not required to take any action beyond that which is reasonable under the circunistances. In the case of an ill or injured person, he will seldon be required to do nore than give such first aid as he reasonably can, and take reasonable steps to turn the sick man over to a physician, or to those who will look after him and see that medical assistance is obtained." RESTATEMENT (SECOND) OF TORTS, § 314A comment $f$ (1965).

This is not necessarily true of those whose special relationships arise by contract. Firefighters nay well be required to undergo some significant degree of risk to fulfill their duty to aid those in burning bnildings. But even firefighters are not required to risk death in order to save those dependent on their aid. At any rate, any special relationship that may exist between a pregnant wounan and her fetus would not arise by contract. But see supra note 114 (issue of contracting for surrogate pregnancy).

132. See, e.g., C. MORRIS, MORRIS ON TORTS ch. VI, $\$ 2$ (2d ed. 1980) (requirement of due care if one undertakes to render aid); W. PROSSER \& W. KEETON, supra note $99, \S 56$ ("Where the duty to rescue is required, it is agreed that it calls for nothing nore than reasonable care under the circumstances."); $c f$. J. LeE \& B. LiNDAHL, MODERN TORT LAW $§ 3.41$ (1988) ("The so-called 'good samaritan' inust use reasonable care once he or she has undertaken a mission of mercy. Under this application of the voluntary undertaking principle, a store owner is held to the duty of due care toward a customer once employees undertake to give aid.").

133. See supra note 123 and accompanying text.

134. For example, Jehovah's Witnesses behieve that certain bodily intrusions, such as a blood transfusion, are wrong. See In re President \& Directors of Georgetown College, 331 F.2d 1000, 1002 (D.C. Cir.), cert. denied, 377 U.S. 978 (1964); Raleigh Fitkin-Paul Morgan Memorial Hosp. v. Anderson, 201 A.2d 537, 537-38 (N.J. 1964). 
privacy, dignity, freedom to choose, liberty of movement, sense of inviolability, pride, control over her own reproduction, control over her own health decisions, ability to avoid fearful situations, and indeed her feelimg of equal worth as a person. ${ }^{135}$

Thus, if we agree that there ought to be a mother-fetus special relationship similar to a parent-child relationship, the pregnant woman could, like a parent, be required to aid the fetus by exercising reasonable care, such as by taking vitamins and by gomg for prenatal checkups. But even assuming that a mother-fetus special relationship is more special than a parent-child relationship and therefore permits placing more of a burden on the pregnant woman, once the burden to the woman becomes significant enougl, her obligation to aid the fetus sliould cease.

We must therefore determine liow significant the burden or risk to the pregnant woman must be before her duty to aid the fetus ${ }^{136}$ terminates. While risk to the woman does not correlate absolutely with the degree of invasiveness of the procedure (since some women may liave severe allergic reactions to mere vitamins), surgery is always mvasive.

There is something distinctive about liow our society feels about surgery as opposed to other bodily mvasions. While bodily integrity is generally protectable, this is not an absolute right. Minimal bodily imtrusions such as compulsory blood sample withdrawal and coinpulsory vaccination have been ruled justifiable against competent persons who refused them. ${ }^{137}$ Even so, the Supreme Court lias refused to upliold major bodily imtrusions, such as surgery, for the sake of criminal justice. In Winston v. Lee, ${ }^{138}$ the pohce wanted to obtain a bullet as evidence of a suspect's criminal involvement by ordering the bullet surgically reinoved from his chest. The Court upleeld the demal of surgery, reasoning that

135. See G. ANNAS, supra note 4 (discussing the view of the pregnant woman as an incubator).

136. We should bear in mind that in this discussion we have assumed for the sake of argument that a fetus has a status that is morally significant enough to limit the autonomy of other persons, preventing them from causing it harm.

137. Schmerber v. California, 384 U.S. 757 (1966) (compulsory blood sample does not violate fifth amendment privilege against self-incrimination); Jacobson v. Massachusetts, 197 U.S. 11 (1905) (compulsory vaccination appropriate even in the face of claim of religious exemption). Courts have been willing to go much further in ordering incompetent patients to undergo invasive procedures for the benefit of others, including major organ donation surgery, on the grounds that the incompetent person would have wanted to help the recipient relative. See, e.g., Hart v. Brown, 29 Conn. Supp. 368, 289 A.2d 386 (1972) (allowing parents to consent to kidney transplant from one minor child to another); Strunk v. Strunk, 445 S.W.2d 145, 146 (Ky. Ct. App. 1969) (affirning lower court's judgment that the incompetent child's well-being "would be jeopardized more severely by the loss of his brother than by the removal of a kidney"); Little v. Little, 576 S.W.2d 493 (Tex. Civ. App. 1979) (allowing mother to consent to kidney transplant from Down's Syndrome daughter to dying son); see also Robertson, Organ Donations by Incompetents and the Substituted Judgment Doctrine, 76 Colum. L. REV. 48 (1976) (argning that the substituted judgment doctrine produces the proper solution to the problem of nonconsensual harm to incompetent donor).

138. 470 U.S. 753 (1985). 
because "[t]he medical risks of the operation, although apparently not extremely severe, are a subject of considerable dispute,"139 the suspect's health and privacy interests outweighed the state's need for the evidence. ${ }^{140}$ The Court favored consideration of such factors as the size and depth of the mcision, the duration of surgery, the kind of anesthesia, and the risk of subsequent infection. ${ }^{141}$

All of these factors are present and severe im fetal surgery. Even when the techniques are perfected, because it is major surgery, the risks will always include hemorrhage, injury to surrounding tissues and organs, overwhelming infection (sepsis), shock, death, or other coinplications depending on factors in the wornan's medical condition. ${ }^{142}$ There will always be risks of local infection and scarring. Furthermore, the surgeon inay administer a spinal or epidural anesthetic during fetal surgery, ${ }^{143}$ which can cause the woman to suffer low blood pressure and post-spinal headache. General anesthetic, ${ }^{144}$ on the other hand, may cause the woman to inhale her stomach contents (which can lead to pneumonia from lung damage), to suffer low oxygen in the blood, ${ }^{145}$ and in rare cases to experience malignant hyperthermia ${ }^{146}$ (where the body temperature rises dramatically as a reaction to the anesthetic).

Moreover, where a cesarean is involved (for fetal surgery or simple dehivery), there will be the additional risk of uterine rupture at the scar durmg that and future pregnancies or in future dehveries. ${ }^{147}$ In addition, the drugs the woman nuust take every day after the surgery to ward off premature labor may cause the woman to suffer increased heart rate, high blood pressure, fluid build-up in the lungs (pulmonary edema), heart failure, elevated blood sugar, a feeling of warmth or flushing, stoinach irritation, and increased bleeding during the eventual dehvery. ${ }^{148}$

Most important, forcing wonren to submit to fetal surgery over their adamant refusal may likely cause feelings of frustration and powerlessness, ${ }^{149}$ which may in turn delay recovery time and mcrease the risk of

139. Id. at 766 .

140. Id. at 763. The state also had substantial additional evidence. Id. at 765.

141. Id. at 763-65.

142. N. Hacker \& J. Moore, Essentials of Orstetrics AND Gynecology 238-39 (1986).

143. This type of anesthetic would be admimistered in most shunting procedures. Blakeslee, supra note 15 , at $\mathrm{C} 3$, col. 5 .

144. In the case of Baby Mitchell, the woman was given the general anesthetic halathane. Id.

145. Low blood oxygen is not tolerated well by patients with significant coronary artery disease because it limits blood flow to the heart muscle, and in severe cases an inadequate oxygen supply reaches the brain. N. HACKER \& J. MOORE, supra note 142, at 113-15.

146. B. Katzung, Basic and Clinical Pharmacology 304 (3d ed. 1987).

147. Blakeslee, supra note 15, at C3, col. 5; see also Colautti v. Franklin, 439 U.S. 379, 399 (1979) (accepting testimony that future children of a woman who had hysterotomy-a type of cesarean section-would require delivery by cesarean section due to the risk of rupturing the scar).

148. N. HACKer \& J. MOORE, supra note 142, at 207-09.

149. Gallagher, supra note 4 , illustrates these feehings in the following excerpt, which describes 
death. ${ }^{150}$ These risks will not disappear even with perfected fetal surgical procedures. Although the overall risk of any of these comphications may be small, some women do experience them, and there is no way of knowing which woman will be the rare casualty.

Fetal surgery is not a minor imtrusion: it is major surgery. It intrudes further and more radically than blood tests or the other bodily invasions the Court has allowed. ${ }^{151}$ As with any inajor surgery, a woman will always be exposed to some chance of serious harm even when technology renders fetal surgical invasions as safe as possible. Even if the maternal-fetal special relationship gives the woman a duty to aid the fetus by undergoing mildly intrusive procedures that constitute due care (such as check-ups, blood tests, and inoculations), fetal surgery surpasses any such duty because of the risks the pregnant woman faces.

The concept of reasonably foreseeable harm also weighs against a more stringent maternal-fetal duty. Tort law ordinarily imposes a duty to guard against harm only to the extent the harin is reasonably foreseeable. ${ }^{152}$ In all other special relationships, the dominant person voluntarily puts herself in the special relationship, aware of the foreseeable dangers and their associated burdens. Thus, a department store owner

the reaction of one woman to a court-ordered cesarean section. The woman had adamantly refused the surgery for several weeks:

Confronted with the doctor's intentions, the woman and her husband became irate. The husband was asked to leave, refused, and was forcedly [sic] removed from the hospital by seven security officers. The woman became combative and was placed in full leathers, a term that refers to leather wrist and ankle cuffs that are attached to the four corners of a bed to prevent the patient from moving. Despite her restraints, the woman continued to scream for help and bit through her intravenous tubing in an attempt to get free.

Id. at 9-10 (quoting V. Kolder, Women's Health Law: A Feminist Perspective 2 (Aug. 1985) (unpublished manuscript)). The husband committed suicide a few months after his wife's court-ordered surgery. Kolder, Gallagher \& Parsons, Court-Ordered Obstetrical Interventions, 316 NEW ENG. J. MED. 1192, 1193 (1987).

150. Rhoden, supra note 4, at 2003 n.270 (discussing forced cesarean sections: "Although there are no studies . . . of the safety of nonconsensual Cesareans, given the increasing recognition of the impact of emotions on health, it would not be terribly surprising if women having surgery against their will experienced increased morbidity.").

151. The Supreme Court has never passed on the legitimacy of any type of court-ordered maternal surgery for the sake of a fetns. Most of the courts that have ordered or upheld cesareans against the woman's wishes have been trial or intermediate appellate courts. Only a few higher courts have considered the issue of coerced maternal surgery since Roe v. Wade, 410 U.S. 113 (1973). The District of Columbia Court of Appeals in In re A.C., 573 A.2d 1235 (1990), rejected the notion that a terminally ill but competent woman who had refused cesarean surgery must undergo it. Similarly, the Massachusetts Supreme Judicial Court held in Taft v. Taft, 388 Mass. 331, 446 N.E.2d 395 (1983), that a woman could not be forced by her husband to undergo cerclage, or a "pursestring" operation, in which the surgeon sews the cervix closed to help prevent miscarriage from a weak cervix. In Jefferson v. Griffin Spalding County Hospital Authority, 247 Ga. 86, 274 S.E.2d 457 (1981), the Georgia Supreme Court refused to stay the lower court order for a cesarean and blood transfusion, to which the pregnant woman had not consented. See supra note 63 (summarizing Jefferson).

152. See Prosser \& KEETON, supra note 99, § 31; see also supra note 120 (discussing foreseeability). 
goes into businesss because she hopes to make a profit, knowing that she may have to press a button to stop the escalator from time to time; a lifeguard takes the job because she will be well paid, foreseeing that she will have to save drowning people now and then; and parents decide to raise their children (as opposed to giving thein up for adoption or deciding not to have them in the first place) despite the time, money, and caretaking their children will require.

Some might argne that the pregnant woman enters into a special relationship with the fetus because pregnancy results froin a voluntary act. ${ }^{153}$ Voluntariness, however, should be limited by foreseeabihty. In all other circumstances in which the law posits special relationships, those who enter the relationships at least recoguize the burdens they will bear when rendering the aid required of them. Firefighters understand the dangers they will face before they take the job, and parents ought to recognize that they will have to provide for the basic necessities for their children. But no parent reasonably foresees that he will have to donate a kidney for his sick child. Similarly, a preguant woman can reasonably foresee that she will be required to carry the fetus for about nine months, feel nauseated from morning sickness, gain weight, eat more, and be required to seek prenatal advice from a doctor. But no woman reasonably foresees that she will be required to undergo surgery to treat her fetus. Thus, even if pregnancy results from a voluntary act, the motherfetus relationship should require the woinan to guard her fetus against only those dangers she could reasonably foresee.

Furtherinore, even if pregnancy is a voluntarily assumed relationship, it is not necessarily voluntarily maintained. In all special relationships but pregnancy, those in the dominant position can break off the special relationship whenever the dependent is not immediately in need: the shopkeeper can close or sell the shop, and the lifeguard can quit her job. Even the parents can probably place their children in foster care or up for adoption. Failing to escape one of these special relationships, therefore, mdicates a willingness to sustain it and to assume the obligations to aid that are associated with it.

A pregnant woinan, on the other hand, does not have an easy option to escape the relationship with her fetus. Abortion, the only escape, requires an invasive procedure that soine women cannot face, for religious, health-related, moral, or emotional reasons, or due to family and community pressure, or fear of doctors and surgery. In addition, the law

153. Of course, not all pregnancies are intentional. Some are reckless, in cases where the man and woman have intercourse without birth control, or with birth control that is not considered $100 \%$ effective. Others are negligent, in cases where birth control is used but fails from misuse or misplacement. Those pregnancies resulting from rape or from a manufacturing defect in the birth control device are wholly involuntary. 
may not allow abortion as an escape during the entire period of the woman's special relationship. That may mean that unless she chooses to terminate the relationship with her fetus during the first two trimesters, she is trapped in it. ${ }^{154}$ Furthermore, circumstances beyond a woman's control inay deny women the opportumity to abort. Many abortion clinics have closed because of reduced funding; parental or judicial consent inay be required for a pregnant minor; and often crowds of antiabortion protesters gather around the clinics to intimidate pregnant woinen. Failure to abort indicates very hitle about a woinan's voluntariness in maintaining the special relationship with her fetus. ${ }^{155}$ Therefore, she should not have the corresponding obligations of a voluntarily maintamed special relationship.

To suminarize, because of the pregnant woman's umique position to aid her fetus, we have considered whether to place her and the fetus in a special relationship. All other legally recognized special relationships are created and terminated voluntarily. However, the fact that a woman is pregnant indicates notlinig about the voluntariness of this relationship. The law should not construe the fact of pregnancy as giving rise to a special relationship between the woman and the fetus. Yet even if the law recognizes a special nother-fetus relationship, the woman's duties under that relationship should not include having to provide risky aid, which she could not reasonably have foreseen. The burdens and risks the pregnant woman would be obligated to undertake in undergoing fetal surgery are far inore severe and imtrusive than those required of any other dominant person in a special relationship. Therefore, if the law places her in a special relationship, the pregnant woman should have a negative duty not to harm the fetus and an affirmative duty to seek adequate prenatal care, but she should have no affirmative duty to undergo surgery to aid the fetus.

The foregoing discussion has assumed that the status of the fetus has enough inoral significance to impose restrictions on another person's autonoiny. As has been demonstrated, however, our resolution of the apparent conflict of rights within the deontological framework does not depend on the inoral status of the fetus. ${ }^{156}$ As we have concluded, even if

154. Abortion may be restricted by state law after the second trimester unless the woman can show that her health would be damaged by continuing the pregnancy. See Roe, 410 U.S. at 165.

155. See supra note 49.

156. Of course, according the fetus a moral status of anything less than that of a person (which, given the current scholarly debate, is entirely probable), would invalidate any special relationship between a pregnant woman and her fetus. The law would not impose a special relationship because we only limit our autonomy through negative and positive duties for those we recognize as our equals. See generally Dworkin, supra note 91, at 72-73 ("And, if I am to recognize others as equal persons, there is a requirement that I give weight to the way they define and value the world in deciding how I should act."). 
the fetus had full rights of personhood, the pregnant woman's affirmative duty to aid would not include undergoing fetal surgery. We have seen nothing to justify Inaking an exception to ordinary deontological informed consent law on the grounds of the woman's duty to permit the fetus to be treated surgically.

\section{$\mathrm{V}$}

\section{The Need for a Strong Statement of DEONTOLOGICAL LAW}

\section{A. The Context}

In this Section, we will examine why legislators must enact a law specifically statimg that the informed consent doctrime apphes to fetal surgery. To see the necessity of such legislation, consider what would occur in the absence of such law. In the absence of statutory guidance, informed consent law may not prevail. On the contrary, utilitarian interest-balancing could easily predominate. This prospect should frighten us because the factors taken into account in the utilitarian balance tend to be skewed against pregnant women, and against certain pregnant women in particular. Most of the following evidence deals with cesarean sections, where a clear statement of law is equally absent. We will try to imagine how the same sorts of events would oceur in the fetal surgery situation. I conclude that without a clear statement of the law and its subsequent enforcement, decisions by courts and hospitals in fetal surgery cases would be ad hoc, inconsistent, superficial, and utilitarian, trainpling on the rights of pregnant patients.

Medical procedures are not forced equally on all preguant women with ailing fetuses. Studies show that a large proportion of the woinen involved in forced cesarean section cases are poor, single, minority women who do not speak Enghisl. ${ }^{157}$ After a nationwide survey in 1986, Veronika Kolder's teain found that, of the imstitutions surveyed (covering forty-five states and the District of Columbia), there were at least forty-two attempts in twenty-four states plus the District of Columbia during the previous five years to override maternal refusal of treatment. ${ }^{158}$ Of the twenty-one detailed case studies that emerged, $81 \%$ of the women involved were black, Asian, or Hispanic, ${ }^{159} 44 \%$ were uumarried, ${ }^{160} 24 \%$ did not speak Enghish as their primary language, ${ }^{161}$ and all were receiving pubhic assistance or were receiving treatinent free

157. Kolder, Gallagher \& Parsons, supra note 149, at 1193.

158. Id. at 1192. The team knew of three additional attempts in two additional states. Id. at 1194.

159. Id. at $1192-93$.

160. Id. The percentage of unmarried women was derived from a pool of 16 case studies. Id.

161. Id. 
of charge at a teaching-hospital clinic. ${ }^{162}$ Most of the court orders that were granted came through within six hours in $88 \%$ of the cases, and within one hour in $19 \%$ of the cases. ${ }^{163}$ One order was even obtained over the telephone. ${ }^{164}$

Clearly when the fetus suffers sudden distress, which occurred in $47 \%$ of the surveyed cesarean cases, ${ }^{165}$ saving the fetus requires fast action by doctors, hospital lawyers, and judges. The haste to rescue the fetus, however, may sacrifice the pregnant woman's procedural protections. Many of the pregnant women were not given the opportunity to retain counsel, nor was counsel appointed for then by the court. ${ }^{166}$ In the few cases where counsel was appointed, the attorney had little time, if any, to prepare the woman's case before the hearing ${ }^{167}$ or to hire expert witnesses to testify on the woman's behalf. ${ }^{168}$

In most of the surveyed cases, the woinan's refusal of consent was of no importance whatsoever. ${ }^{169}$ Often, the judge heard only the views of the doctor or hospital, which, without a strong statenient of the applicable law, may have been colored by the medical profession's concern for the fetus as a second patient ${ }^{170}$ and by fear of liability sliould the fetus suffer death or damage from nonintervention. Thus, the judge often had no information on which to base a decision apart from what the doctor or hospital presented as the woinan's condition and the fetus' predicament. ${ }^{171}$

Furthermore, as the title of Nancy Rhoden's article suggests ("The Judge in the Delivery Room"), many of the hearings depriving the women of their autonomy rights in cesarean section cases were held riglit in the hospital roon. ${ }^{172}$ Compounding the absence or ill-preparedness of counsel and minimal expert testimony, we must not forget that in the cesarean context the woman is close to delivery, in pain, and undoubt-

162. Id.

163. Id.

164. Id.

165. Id.

166. See Rhoden, supra note 4 , at 2025.

167. Id. at 2025 n.374. Rhoden reports that in Jefferson v. Griffin Spalding County Hospital Authority, $247 \mathrm{Ga} .86,274$ S.E.2d 457 (1981), counsel was appointed for the woman at 11 a.m. and the hearing took place at noon. Id; see also Gallagher, supra note 4, at 48-49 (discussing the procedural deficiencies in the forced treatment of pregnant women).

168. See Gallagher, supra note 4, at 49.

169. Kolder, Gallagher \& Parsons, supra note 149, at 1195.

170. See supra note 12 and accompanying text.

171. I do not believe the judge should consider the predicament of the fetus at all. Nor should the woman's condition matter, except as it relates to her competence to make an informed decision. I simply recognize that a judge may be swayed by such reports.

172. See, eg., Bowes \& Selgestad, supra note 4, at 209-10 (reporting that in one case study, the hearing for a cesarean-refusing pregnant woman was conducted by the judge, attorneys, and expert witnesses in her hospital room). 
edly worried about the health of her near-term fetus. In such weakened and desperate condition, she may be unable to withstand the pressure on her to give in. This is especially true when the doctor whoin she has trusted opposes her, the presence of the judge and hospital lawyers intimidates her, and these authority figures tell her she is wrong. The problem is exacerbated if, as is likely, she does not understand Enghish well enough to know what is happening or to communicate her refusal clearly.

Fear of hability creates a problem because many of the instruments used to detect fetal abnormality have a significant rate of error. ${ }^{173}$ Since doctors have no way of distinguishing between false alarms and actual emergencies, they err on the side of safety by performing the cesarean section. Doctors worry that if they do nothing, despite having warning of the fetus' condition, they could be hable for inalpractice. ${ }^{174}$ This results in a fair number of unnecessary cesarean sections. ${ }^{175}$

The cesarean context differs from the fetal surgery context only in that the pregnant woinan is not as close to delivery in the latter situation. Her doctors will have more time to perform tests to reduce the chances of a false alarm. Waiting a week or two to confirm the condition will not significantly harm a fetus with hydronephrosis, nor will treatment a week or two sooner significantly help the fetus. The inarginal value in treating the condition upon discovery is further reduced because doctors cannot detect inany of the conditions treatable by fetal surgery until the fetus has developed sufficiently, by which time the condition has already had several weeks, if not inonths, to cause progressive damage. Therefore, the fetal surgery context will probably see fewer medically uimecessary operations than the cesarean section context. Yet in the absence of the clear applicability of informed consent law relieving the doctor of responsibility for a defective fetus, a doctor nay seek a fetal surgery court order out of fear of hability.

173. Rhoden, supra note 4, at 1957, 2012-13.

174. Id. at 2009 n.284; Kolder, Gallagher \& Parsons, supra note 149, at 1195.

175. Kolder, Gallagher \& Parsons, supra note 149, at 1195. The article reports knowledge of six cases in which doctors sought court orders for cesareans in situations that turned out to be false alarms. One example is Jefferson, in which the Georgia Supreme Court upheld a court-ordered cesarean because of placenta previa. After the court ordered the cesarean, the woman's condition reversed itself. She delivered a healthy baby vaginally a few days after the court's decision. $G$. ANNAS, supra note 4, at 119-20. Rhoden, supra note 4, at 1959-60, reports that in In re Baby Jeffries, No. 14004, slip op. at 9 (Jackson County, Mich. P. Ct. May 24, 1982), after a court authorized the police to seize a pregnant woman with placenta previa and take her to the hospital against her will for a cesarean, she went into hiding and ended up giving birth vaginally at a different hospital. Similarly, in North Central Bronx v. Headley, No. 1992-85 (Sup. Ct., Special Term, Bronx City, N.Y. Jan. 6, 1986), a woman with hypertension and pre-eclampsia (a condition that can progress into eclampsia, which can cause convulsions dangerous to the woman and fetus), refused a cesarean. After the court ordered a cesarean, the woman never came back to the hospital, dehivering a baby vaginally at home. 
Since the fetal surgery context allows inore time, the woman refusing doctor-recommended fetal surgery has time to find a lawyer, prepare her case, and find experts to testify on her behalf. If required, she may also have time to find a translator to help her understand the situation, the fetus' condition, and the discussion at any subsequent hearing. Absent time constraints, the hearing can take place in a courtroom rather than at a hospital bedside. Because the procedure is not as urgent, the woman threatened with fetal surgery against her will may thus fare better than her cesarean counterpart, even without the guarantee of informed consent law.

Nevertheless, the woman faced with fetal surgery will agonize no less than the woman faced with cesarean section in deciding whether to help her fetus or to insist on her right not to do so. The woinan will have to make the same difficult decision about whether to help the fetus or give in to considerations relating to her rehious behiefs, her fear of surgery, surgical comphications, or problems with later preguancies, her worry over how to care for the rest of the family, or her concern over time lost froin work, among other reasons. She knows she should trust her doctors, but when they tell her she ought to have the operation, she knows they do not have just her best interests in inind. Furthermore, whereas in the cesarean cases the woinan inay risk her health if she declines surgery, ${ }^{176}$ in the fetal surgery cases only the fetus' health is at risk. This fact will likely inake the woinan even inore reluctant to submit to fetal surgery. Yet to stand her ground in the face of pressure to have the surgery takes great strength and powerful convictions. The pressure to give in could be overwhelming.

If fetal surgery becoines as routine as cesarean section and ad hoc utilitarian balancing prevails, the victims may well be poor minority women who do not speak Enghish. ${ }^{177}$ They will be unable to pay for high-powered lawyers and high-profile experts. Doctors may attempt to declare the woinen incompetent because of their lack of education or information. Doctors may even try to proceed with the surgery without asking the woinen because of the women's inability to communicate, which inay create the impression that the women are unable to understand what they are told or are inerely stupid. Minority women may be less aware of their rights because their rights are often disregarded.

These women, however, are exactly those who should be particularly encouraged to seek prenatal care. If doctors resort to forced surgery, they will discourage these woinen froin seeking prenatal care altogether. As was the case with the pregnant women in Jefferson $v$.

176. In cases like Jefferson, where the woman has placenta previa, vaginal delivery may be fatal to both her and the fetus due to the woman's uncontrollable hemorrhaging. See also supra note 89.

177. See supra text accompanying notes 157-62. 
Griffin Spalding County Hospital Authority, ${ }^{178}$ In re Baby Jeffries, ${ }^{179}$ and North Central Bronx v. Headley, ${ }^{180}$ the threat of court-ordered surgery will drive women into hiding and possibly out of the hospital system entirely. In the fetal surgery area, since the threat of surgery occurs earlier than in the cesarean cases, women will stop seeking prenatal care earher in the pregnancy, if not from the start.

Courts probably will not decide many of the forced fetal surgery cases. That is to say, even without a court order, doctors may have a great deal of power to pressure women into consenting to the recommended surgery. Psychological factors intensify this pressure so that, in many cases where women finally give consent, they do not give it freely and voluntarily. ${ }^{181}$

A coercive method that the doctor may consciously or unconsciously use is called the "foot-in-the-door" technique. ${ }^{182}$ Studies have slown that the likelihood of a person's consenting to a subsequent request-even a substantially larger or more burdensome requestincreases dramatically if the person has complied with an initial sinall request. ${ }^{183}$ For example, the initial prenatal checkup leads to an ultrasound examination, which leads to a series of blood tests and an amniocentesis. At each step, the doctors share with the woman the new information about her fetus: they show her the image of the fetus projected by the ultrasound, they tell her whether the amniocentesis predicted a boy or a girl, and so on. By increasing the woman's involveinent in the treatment of the fetus, and by stepping up the interventions hittle by little, once the tine arrives for her to decide about fetal surgery, fetal surgery no longer seeins like a big leap from the previous step. The clioice may no longer be effectively hers.

That the person making the mcremental requests is an authority figure only amplifies the foot-im-the-door technique. Furthermore, few woinen seeking prenatal care expect problems serious enough to require surgical imtervention for the fetus. By the time doctors discover the

178. $247 \mathrm{Ga} .86,274$ S.E.2d 457 (1981).

179. No. 14004, slip op. at 9 (Jackson County, Mich. P. Ct. May 24, 1982).

180. No. 1992-85 (Sup. Ct., Special Term, Bronx City, N.Y. Jan. 6, 1986).

181. See Thompson, Psychological Issues in Informed Consent, in President's Commission for the Study of Ethical Problems in Medicine and Biomedical aNd Behavioral Research, 3 Making Health Care Decisions: The Ethical and legal Implications of INFORMEd CONSENT IN THE PATIENT-PRACTITIONER RelationShip 83, 85 (1982) ("If patients are unable to assert their own preferences in the face of social pressures in the medical setting, leaving the decision nominally in their hands does not protect their autonomy.").

182. Id. at 104 .

183. Id. (citing findings confirmed many times since, and imitially reported in Freedman \& Fraser, Compliance Without Pressure: The Foot-In-The-Door Technique, 4 J. PERS. \& Soc. PSYCHOLOGY 195 (1960)). 
fetus' problem, the woman is already well entrenched in the progression that will lead her to choose fetal surgery.

Another coercive method has been called "the tyranny of available technologies."184 Scientists and doctors use experimental technology reluctantly, if at all, because they fear it may cause more harm than good. Similarly, doctors hesitate to recommend a procedure, because they fear raising false hopes. Nevertheless, as the technology develops and improves, it gains wider acceptance and use among the medical and scientific communities, and "[w] hat was originally an optional technology may quickly become the norm." 185

Furthermore, once the technology exists and works, it is nearly impossible not to use it. ${ }^{186}$ Ultrasound technology provides a clear example. What woman would refuse an ultrasound exam now that the technology to see one's fetus and its possible physical problems exists and works? ${ }^{187}$ Another example is ammocentesis, which is a more invasive procedure than ultrasound testing, but which is now fairly routine. Cesarean sections also, to some degree, provide such an example. Fetal surgery too may soon become routine, once surgical techniques are perfected and widely accepted as effective. As with cesarean sections, once fetal surgery exists as a technology to help the fetus, doctors may feel pressure to use it, women to accept it, and judges to order it.

Other factors complicate fetal surgery cases. In the cesarean section cases, where vaginal dehivery is the only threat to the otherwise healthy fetus, the surgical procedure resolves the fetus' health probleins, and the baby is born perfectly healthy. In the fetal surgery context, however, the surgery may only preserve the fetus' life without making it healthy.

Fetuses with hydrocephalus, rarely a fatal condition by itself, often have other defects that, in combination, may well be fatal. ${ }^{188}$ With the

184. Lauritzen, What Price Parenthood?, 20 Hastings CeNTER REP., Mar.-Apr. 1990, at 38, $39-41$ (discussing the method in the context of in vitro fertilization technology).

185. Id. at 40 .

186. See id. at 41 ("If surgery might repair the problem, even if the chances are not great, how can I not have surgery?"). Similar concerns were voiced by Robert Oppenheimer, fearing that if the hydrogen bomb were developed it would be used, and by Andrei Sakharov, after developing the hydrogen bomb, that it would be used in waging war, not merely in deterring war. The events at Hiroshima and Nagasaki vindicated their fears. See A. SAKHAROV, MEMOlRs 97-100 (R. Lourie trans. 1990).

187. On the other hand, if she did refuse ultrasound, her doctors would never know that fetal surgery was required. This would be a way of avoiding any possibility of fetal surgery.

188. Experimenters shunting fetal hydrocephalus had to be careful to take on only those fetuses with hydrocephalus alone and not in combination with other conditions, so that their rates of success in treating hydrocephalus would not be affected or indeed entirely negated by the damaging effects of the other conditions. Clewell, supra note 22, at 93; see also Frigoletto, Birnholz \& Greene, Antenatal Treatment of Hydrocephalus by Ventriculoamniotic Shunting, 248 J. A.M.A. 2496, 2497 (1982) ("The hydrocephalus should not be associated with other major malformations that are themselves incompatible with survival or that indicate an irrenediable malformation syndrome."). 
hydrocephalus treated, the fetus may survive, but just barely. The pregnant woman may very well prefer not to raise the unhealthy baby that survives such surgical intervention; the woman might prefer to let the fetus die of its defects before birth. ${ }^{189}$ The child would require much time, inoney, labor, and care, draining these resources away from other family members. ${ }^{190}$ To some parents, raising such a child inay give hittle satisfaction and cause great emotional strain. Yet without a clearly controlling law that allows women to refuse treatment, doctors who opt for fetal surgery inay fail to consider this burden and thus unwittingly force it onto woinen and their families.

A related problem may occur during the period when the pregnant woinan can still legally abort the fetus. Clearly, she could avoid undergoing fetal surgery by simply aborting the fetus. In fact, when woinen discover, by amniocentesis or other inethods, that the fetus is defective, nearly all woinen abort. ${ }^{191}$ The existence of the fetal surgery option may pressure pregnant woinen during the pre-viability period into choosing surgery rather than abortion in the hope that the fetal surgery will give them a normal baby. ${ }^{192}$ In the fetal hydrocephalus exainple, a woman who chooses surgery rather than abortion will get a severely mentally and physically handicapped-but living--baby. ${ }^{193}$ The parents are now burdened with the cost and effort of raising a disabled child, having been led on by the hope of helping their fetus, only to find that helping ineans saving its life but not necessarily curing it. Yet without an applicable law that requires fully informing the patient of options and outcomes, the possibility of informed refusal is illusory.

A final problein complicates the fetal surgery situation. At present, doctors cannot detect many fetal conditions until close to or after fetal viability. Doctors rarely diagnose hydrocephalus before twenty weeks of

189. Cf. supra notes 100-02 and accompanying text (discussing deontological justification for letting solneone die or permitting harm). Note that this parallels the current hospital practice of honoring parents' refusal of lifesaving treatment for defective newborns who with treatment will he but will never be healthy; Jurow \& Paul, supra note 4, at 597 (reporting that in one case study, a woinan who required an emergency cesarean section to save her distressed fetus refused, saying that "if the fetus would die, it would solve her already-complicated life situation.").

190. Of course, refusing fetal surgery imposes a great burden on the resulting disabled child, the family, and society, in terms of the increased financial and other costs of its care. We do not, however, require women to abort fetuses that they discover before birth to be defective. Nor do we eliminate people from society if they develop disabihities. The added cost to society of caring for people born witl or subsequently developing disabilities is one our society is willing to tolerate. That does not mean that one particular woman should have to tolerate such cost if she does not so choose.

191. Rhoden, supra note 4, at 2008.

192. The advent of effective fetal surgery inay possibly lead to further judicial erosion of the woinan's right under Roe v. Wade, 410 U.S. 113 (1973), to seek an abortion at all. The ability to save the fetus or even in some cases to cure it may make its viability or its potential personhood seem more actual at an earlier point, an important argument for fetal rights advocates.

193. Clewell, supra note 22, at 90,96 . 
pregnancy, ${ }^{194}$ when abortion may no longer be a realistic legal option. ${ }^{195}$ Thus, the woman would not have the option of avoiding fetal surgery by aborting the defective fetus. Requiring fetal surgery for all fetuses that need it and that have not been aborted by the woman im time ${ }^{196}$ will simply encourage earlier abortion among pregnant women unsure of their commitment to undergo possible future fetal surgery. The logical extension of the fetal rights position in the fetal surgery context could, iromically, mcrease the number of abortions. A law that allows refusal of fetal surgery during the entire course of the pregnancy avoids this result.

Obviously, as many authors liave pointed out, improveinents in the health care system generally and in prenatal care specifically would do more overall to help fetuses and babies than would requiring extreine imterventions such as fetal surgery and cesarean section. ${ }^{197}$ But courts have ordered cesarean sections over women's refusals, and may likewise order fetal surgery some day. A deontological law specifically stating that the informed consent doctrine applies to fetal surgery decisions would bring order to a troubling area that until now has not been adequately addressed.

\section{B. A Proposed Statute}

We have resolved the apparent conflict between the pregnant woman's rights and duties and found that the woman has no duty to undergo fetal surgery agamst her will. I propose, therefore, the following properly deontological fetal surgery law that follows ordinary inforned consent law:

(1) If a pregnant woman is competent to make a decision, and

(2) If her fetus requires surgery at any time before birtli, then

(3) Before the surgery is performed she must be objectively informed of the following:

(A) that her fetus requires surgery before birth;

(B) that treating the fetus will require her to undergo surgery;

(C) the nature of the surgery and its risk to her health;

(D) the likely condition of the fetus with surgery; and

(E) the likely condition of the fetus without surgery.

194. Id. at 93.

195. Under the present state of the law, Roe $v$. Wade allows the states to "regulate the abortion procedure in ways that are reasonably related to inatemal health" during the second trimester. 410 U.S. at 164. This means that although the woman still has a legal right to abortion, a state can essentially "regulate" the availability of abortion out of existence.

196. This is as far as most fetal rights advocates are willing to go. See supra notes $48-61$ and accompanying text.

197. See Gallagher, supra note 4, at 56; Nelson \& Milliken, Compelled Medical Treatment of Pregnant Women: Life, Liberty, and Law in Confict, 259 J. A.M.A. 1060, 1065 (1988); Rhoden, supro note 4, at 2028-29. 
(4) If she refuses the procedure after being thus informed, her decision inust be respected.

(5) Although her doctor may give her advice if she requests it, the doctor may not attempt to persuade, coerce, or intimidate the woinan to consent or refuse.

(6) No doctor, hospital, or other entity may be held hable for the resulting ill health or death of any fetus for which treatment is refused under this statute.

This statute follows informed consent law in its dual aims of providing for information and choice. ${ }^{198}$ It provides for disclosure to the competent patient of information material to her decision about the proposed medical procedure, including the risks mvolved in undergoimg the procedure and the likely result both with and without the treatment. It also provides for an opportunity to refuse the procedure. This approach properly embodies the usual deontological model involved in doctorpatient decisionmaking, in that it is rights-based, since it does not compare the benefit to the fetus with the harm to the woman. ${ }^{199}$ Moreover, the statute properly reflects the resolution of rights and duties involved in the fetal surgery conflict in favor of the pregnant woman, who has no duty to undergo surgery on behalf of the fetus. ${ }^{200}$ She is given the sole choice to refuse or consent to the recommended surgery.

Perhaps most important, the statute seeks to ensure that a pregnant woinan's refusal of fetal surgery will be respected, in that the statute both prohibits coercive tactics and reheves doctors and others who comply with the statute of any liability for the untreated fetus' resulting condition. This proposed statute provides woinen, doctors, hospitals, courts, and lawyers with the guidance currently lacking in the fetal surgery area.

\section{CONCLUSION}

The ability of doctors to treat certain fetal defects is a promising new developinent in the field of medicine. However, the apphicable law dealing with the riglits and duties of the pregnant woinan when her doctor recommends fetal surgery has been unclear. To prevent ad loc decisionmaking by courts and hospitals, there must be a clear statement of applicable law.

This Comment has argued that the deontological model, as embodied in the doctrine of informed consent, is the proper framework for a fetal surgery law. Although pregnancy presents a umque situation, where treating the fetus necessarily imvolves operating on the woman,

198. See supra text accompanying notes $78-80$.

199. See supra text accompanying notes 37-46.

200. See supra text accompanying notes 136-56. 
this does not justify switching to a utilitarian model that balances the benefits to the fetus against the risks to the woinan.

Given that the deontological model is proper, it is necessary to resolve the conflict between the autonomy right of the pregnant woman to refuse surgery and the duty she may owe to the fetus. This Comment has argued that any such duty does not rise to the level of requiring the woman to aid the fetus by undergoing surgery. First, there is ordinarily no affirmative duty to aid another person, although there is a negative duty to refrain from harming another. In the fetal surgery context, only the affirmative duty is implicated, since there is nothing the woman can stop doing that will help the fetus. Second, any special relationship that the preguant woman inay have with the fetus requires only that she act with reasonable care under the circumstances, or at inost to undertake minimally burdensome measures of aid. A special relationship would not require the pregnant woman to put her life or health at risk to rescue or aid the fetus. Given the risks inherent in any major surgery, she has no duty to undergo surgery for the benefit of the fetus.

This Comment bolsters that conclusion with evidence of what would likely happen to pregnant women in the absence of a strong statement of deontological law. Finally, the Comment closes with a proposed statute consistent with informed consent primciples. Although fetal surgery is still in its experimental stages and has not yet been imposed on a wornan against her will, the same could once have been said about cesarean section. The time to consider and resolve the apparent conflicts involved in fetal surgery is before any rights get trampled. This Comment resolves the conflict by giving the pregnant woinan the right to refuse. 